
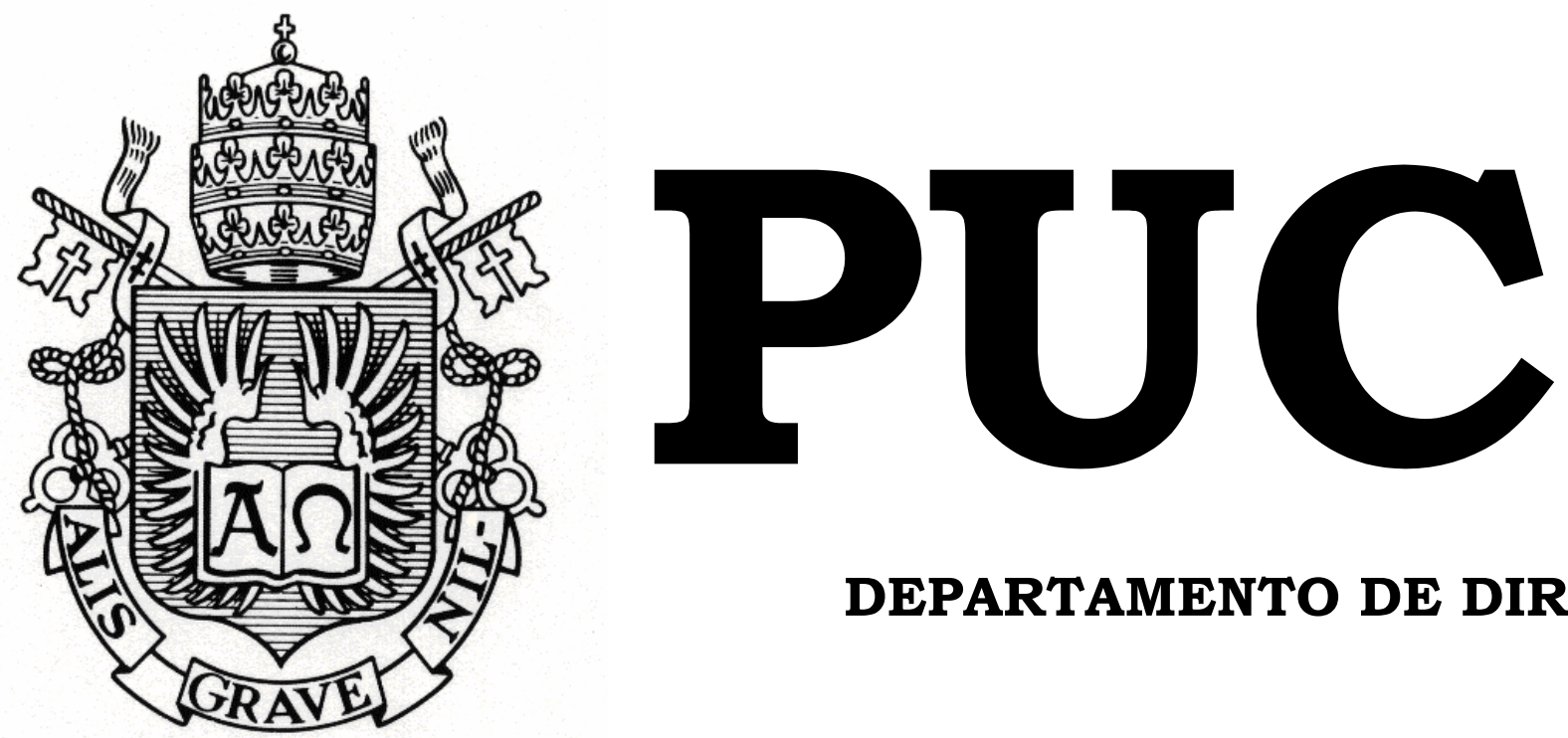

DEPARTAMENTO DE DIREITO

\title{
A Publicidade Enganosa e Abusiva \\ e \\ a Responsabilidade dos Envolvidos \\ por
}

ADRIANA FIGUEIREDO FERNANDES

orientador:

DANIELE MEDINA MAIA

2005.1

PONTIFÍCIA UNIVERSIDADE CATÓLICA DO RIO DE JANEIRO

RUA MARQUÊS DE SÃO VICENTE, 225 - CEP 22453-900

RIO DE JANEIRO - BRASIL 


\section{A Publicidade Enganosa e Abusiva \\ e \\ a Responsabilidade dos envolvidos}

por

\section{ADRIANA FIGUEIREDO FERNANDES}

Monografia apresentada ao

Departamento de Direito da

Pontificia Universidade Católica do

Rio de Janeiro (PUC-Rio) como requisito parcial para a obtenção do Título de Bacharel em Direito.

Orientador: Daniele Medina Maia 


\section{AGRADECIMENTOS}

Agradeço à minha mãe Daisy, presença fundamental em meus estudos, pelo incentivo dado ao longo do curso, à minha avó Guida, pelo carinho especial nos ensinamentos da vida, e à minha irmã Renata, pela paciência em me ceder o computador.

Ao meu noivo Bruno, pelo amor e compreensão.

Aos colegas e amigos da universidade, principalmente, a Noele e a Samasse, pela amizade e apoio.

À Professora Daniele Medina Maia com quem tive a oportunidade de aprender e o privilégio de tê-la como orientadora.

À Pontifícia Universidade Católica do Rio de Janeiro - PUCRio por ter proporcionado meus estudos. 


\section{SUMÁRIO}

Resumo

Introdução 5

Capítulo I - Histórico

$\begin{array}{ll}\text { Capítulo II - A Publicidade } & 10\end{array}$

2.1 A Publicidade e o Código de Proteção e Defesa do Consumidor $\quad 12$

2.2 Publicidade e Propaganda 13

2.3 Publicidade Institucional e Promocional 15

2.4 Outras formas de Publicidade 16

$\begin{array}{ll}2.5 \text { Publicidade Enganosa } & 19\end{array}$

2.6 Publicidade Abusiva 26

2.7 Técnicas da Publicidade 32

2.8 O Princípio da Veracidade 33

Capítulo III - A Responsabilidade dos Envolvidos 38

3.1 Responsabilidade Administrativa 40

3.2 Responsabilidade Penal 42

3.3 Responsabilidade Civil 44

3.4 A Responsabilidade dos Fornecedores 47

3.5 A Responsabilidade das Agências de 49

Publicidade

3.6 A Responsabilidade das Celebridades $\quad 50$

3.7 A Responsabilidade dos Veículos de Divulgação 53

Conclusão $\quad 56$

Bibliografia $\quad 59$

Anexo: Jurisprudência $\quad 62$ 


\section{RESUMO}

O consumismo exagerado é a característica principal do capitalismo moderno e reflete a necessidade da circulação das massas de bens acumulados. Para isso, não basta apenas procurar conhecer as vontades mais profundas e escondidas dos consumidores.

O aumento do consumismo depende da divulgação dos produtos e serviços por meio da publicidade. Esta, nos dias de hoje, é, na maioria das vezes, mais importante que a própria qualidade do produto ou serviço oferecido.

Por outro lado, existem empresas que apelam para estratégias de marketing agressivas e veiculam publicidade enganosa ou abusiva, com o intuito de vender produtos cuja qualidade nem sempre está de acordo com as normas técnicas. Não se preocupam com os verdadeiros interesses dos consumidores, como a segurança e a qualidade, e muito menos com as expectativas de outras empresas do mesmo ramo de atividades, ferindo a livre concorrência do mercado, sem contar, que prejudicam o próprio Estado, que tem o interesse em um mercado competitivo e legal.

Sendo assim, o presente estudo tem como objetivo tecer algumas considerações sobre os interesses dos consumidores tutelados pelo Código de Defesa do Consumidor, que estabeleceu o princípio da responsabilidade do fornecedor à oferta e à publicidade. Fora isso, também será bastante discutido a respeito da preservação da integralidade dos valores que estão protegidos pelo aludido Código, analisando-se a responsabilidade das pessoas que contribuíram para o anúncio, uma vez que é inegável a importância delas na difusão do consumismo. 


\section{INTRODUÇÃO}

É de conhecimento de todos a importância econômica e educativa $^{1}$ da publicidade lícita para o mercado consumidor. Nossa inteligência humana, primeiro descobriu o poder da publicidade na alteração de condutas, na criação de mercados, no desenvolvimento da economia, e posteriormente, esta mesma inteligência do homem com capacidade de criação, descobriu como tornar uma publicidade ilícita, enganando o consumidor, levando o receptor da oferta ao erro, causando-lhe até mesmo danos.

A publicidade é necessária ao desenvolvimento do mercado, mas ao mesmo tempo também pode ser muito danosa. Não podemos censurar à criatividade humana, mas temos a obrigação de utilizar o bom senso, tratando a publicidade como vital à sociedade, porém, respeitando a adequada regulamentação.

No presente trabalho monográfico inicialmente serão discutidos os aspectos históricos e teóricos da publicidade, seus efeitos frente ao consumidor, bem como a diferenciação entre os termos "propaganda" e "publicidade" e publicidade "institucional" e "promocional", além de um breve comentário sobre outras formas de publicidade.

A questão seguinte a ser levantada será a contraposição entre a Publicidade Enganosa e a Publicidade Abusiva. Após esta discussão, será tratado o Princípio da Veracidade inerente ao Direito do Consumidor. O Capítulo será finalizado com a análise de outras

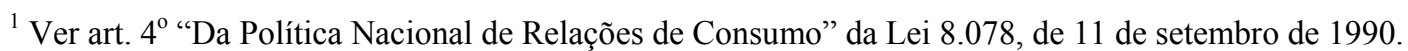


técnicas que são utilizadas pelo meio publicitário com a finalidade de induzir o consumidor ao erro.

Em capítulo posterior, será tratada a questão da Responsabilidade em torno da matéria publicitária conduzida de forma ilícita, seja através responsabilidade administrativa, criminal e civil, ressaltando a responsabilidade de cada um dos envolvidos, que são eles: os fornecedores, as agências publicitárias, os apresentadores de programas, incluindo os atores famosos, e os veículos de divulgação.

O tema "A Publicidade Enganosa e Abusiva e a Responsabilidade dos Envolvidos" reflete uma preocupação com a maneira que os publicitários estão tratando a sociedade civil brasileira. Não existindo limites quando se fala em lucros.

A doutrina está constantemente preocupada em afirmar que o consumidor antes de tudo é vulnerável e hipossuficiente, e por conta disso é preciso a conscientização dos consumeristas a fim de lutar de forma igualitária com os publicitários, que estão muito à frente dos consumidores. 


\section{CAPÍTULO I - HISTÓRICO}

$\mathrm{Na}$ sociedade pré-industrial as mercadorias eram produzidas de forma manufaturada e em baixa escala. Não era exigido o esforço excessivo do fabricante para colocar os produtos no mercado uma vez que os vendedores e os compradores se conheciam e prevalecia uma confiança nas relações de consumo.

O século XIX foi marcado com profundas mudanças sociais e econômicas que sucederam a revolução industrial. A publicidade surgiu em meados do século supra mencionado basicamente como uma comunicação informativa entre vendedor e comprador. A relação entre eles era fundada no conhecimento pessoal e na confiança, como na sociedade pré-industrial, e refletia o conceito de seriedade e honestidade do vendedor, que assumia garantia a qualidade da mercadoria. ${ }^{2}$

Tendo em vista a produção em série, conseqüência da revolução industrial, a partir do século XX, o consumo tornou-se massificado, ou seja, os produtos que eram destinados a um indivíduo em especial, estendeu-se a toda a coletividade. A publicidade, então, antes, de caráter individualista, passou a ser endereçada a todos com a finalidade de colocar no mercado toda a produção.

No entanto, para a existência de uma relação de consumo, é indispensável conhecimento de dois conceitos fundamentais: Fornecedor e Consumidor.

Fornecedor, conforme o art. $4^{\circ}$ da Lei 8.078/90, "é toda pessoa física ou jurídica, pública ou privada, nacional ou estrangeira, bem

\footnotetext{
2 PASQUALOTTO, Adalberto. Os Efeitos Obrigacionais da Publicidade no Código de Defesa do Consumidor. São Paulo: Revista dos Tribunais, 1997, 28 p.
} 
como os entes despersonalizados, que desenvolvem atividades de produção, montagem, criação, construção, transformação, importação, exportação, distribuição ou comercialização de produtos ou prestação de serviços".

Por outro lado, “consumidor é toda pessoa física ou jurídica que adquire ou utiliza produto ou serviço como destinatário final" (art. $2^{\circ} \mathrm{da}$ lei supra citada).

Definir quem é consumidor é um dos temas mais abordados pela doutrina. O que não ocorre sem razão, pois a lei especial acima mencionada tem o objetivo de justamente proteger o consumidor. Por isso, é importante retratar duas correntes que se preocuparam em definir o termo "destinatário final".

Inicialmente, há a corrente finalista ou teleológica, que considerando o caráter restritivo da expressão destinatário final, entende que consumidor é o não profissional, aquele que adquire bem ou serviço para uso próprio ${ }^{3}$.

Em oposição aos finalistas, os maximalistas enxergam algo mais amplo, dirigido não à pessoa do consumidor, mas ao mercado de consumo. Sendo um código das relações de consumo, deve o art. $2^{\circ}$ ser interpretado da forma mais ampla e objetiva, e compreendendo "destinatário final" como àquele que retira o bem do mercado, não importando uma análise subjetiva, ou teleológica, de qual a finalidade ou destinação que o objeto da relação receberá. ${ }^{4}$

\footnotetext{
${ }^{3}$ CASADO, Márcio Mello. Proteção do consumidor de crédito bancário e financeiro. São Paulo: Revista dos Tribunais, 2000, $31 \mathrm{p}$.

${ }^{4}$ EFING, Antônio Carlos. Contratos e Procedimentos Bancários à Luz do Código de Defesa do Consumido. São Paulo: Revista dos Tribunais, 2000, p.46-47.
} 
$\mathrm{Na}$ jurisprudência, a tendência atual se apresenta em conformidade com a doutrina dominante, finalista, tendo os magistrados percebido qual a real intenção do legislador, criando o Código Proteção e Defesa do Consumidor (“CDC"), a Lei $n^{0}$ 8.078/90, como norma especial. 


\section{CAPÍTULO II - A PUBLICIDADE}

A comunicação apareceu como uma grande característica da nossa sociedade. As últimas notícias, as tendências, os acontecimentos, as novidades sobre produtos e serviços são transmitidos às pessoas através dos meios de comunicação.

O desejo incessante de consumir também é uma característica marcante que faz de nós uma sociedade extremamente consumista. A procura por produtos para o consumo não se resume somente a bens indispensáveis para a subsistência, os dispensáveis e supérfluos também têm bastante circulação no mercado. Entretanto, para saciar o desejo consumidor e garantir a possibilidade de escolha é necessário que exista um conhecimento prévio sobre quais produtos ou serviços estão no mercado a disposição das pessoas. Incumbe-se essa tarefa ao meio publicitário.

No entanto, a publicidade não pode ser entendida apenas como informação. Se analisarmos mais profundamente, vamos concluir que publicidade é também persuasão. Quando o publicitário veicula um anúncio, espera-se não apenas informar o consumidor a respeito da existência daquele produto ou serviço, mas principalmente vender o que está sendo anunciado. A mensagem publicitária tem o condão de angariar simpatia por um produto ou serviço.

Através da publicidade as empresas vêm conseguindo aumentar espaços no mercado com produtos supérfluos e que fazem crer aos consumidores, via mensagens persuasivas, serem indispensáveis na nossa sociedade de consumo, sob pena daquele indivíduo que não os 
adquirir ser discriminado pela mesma sociedade. É um método que serve para atingir os consumidores de uma forma mais eficaz, e pode-se dizer mais lucrativa para as empresas que anunciam. Não podemos esquecer que um espaço na televisão em horário nobre custa bastante dinheiro, porém, torna-se uma quantia desprezível se comparada ao retorno. É uma atividade importantíssima para a geração de riquezas podendo-se dizer que a economia moderna não sobreviveria sem ela. Ela, sem dúvida, é o principal meio para o capitalismo atingir seu objetivo.

A publicidade exerce poderosa influência sobre a vida das pessoas, seus padrões de comportamento, seus hábitos, suas idéias e seus valores, atingindo homens, mulheres e crianças. Ela exerce significativa influência sobre os componentes psicológico e emocional dos seres humanos, e não de meros consumidores autômatos. Através dela vende-se de tudo.

Como ilustração, foi realizada uma pesquisa na Universidade Federal do Paraná com um grupo de crianças onde os resultados foram que elas estão sendo controladas pelas marcas mais famosas, mesmo em produtos para adultos (como carros, cigarros, cerveja). Elas continuaram citando a marca preferida mesmo logo após terem assistido a um filme intercalado com propagandas de outras marcas do produto.

A pesquisa foi realizada com 50 (cinqüenta) crianças de 10 (dez) anos que passaram por 2 (duas) sessões: na $1^{\mathrm{a}}$ (primeira) sessão (ou préteste), elas assistiram a um filme e ao final responderam por escrito questões referentes à preferência sobre produtos qual lembravam mais (refrigerante, iogurte, cerveja, cigarro, carro e chocolate). 
$\mathrm{Na} 2^{\mathrm{a}}$ (segunda) sessão, apresentaram um novo filme onde foram intercaladas propagandas de TV dos mesmos produtos perguntados anteriormente. No entanto, as marcas dos produtos anunciados durante o segundo vídeo foram aquelas que não apareceram citadas na primeira vez pelas crianças. No final, as crianças responderam 2 (dois) tipos de questionários: no $1^{\circ}$ (primeiro) tinham de colocar "a palavra que vinha a cabeça" e o $2^{\circ}$ (segundo) questionário incluía perguntas que foram as mesmas da $1^{\text {a }}$ (primeira) sessão.

A pesquisa mostrou que as repostas da primeira sessão estão vinculadas às propagandas de produtos famosos e mais veiculados pela TV. Mostrou ainda que uma exposição a novas propagandas, na segunda sessão, não foi suficiente para alterar significativamente suas respostas.

Assim, a influência da publicidade de marcas famosas são extremamente poderosas e incorporam-se à vida. Influem até mesmo em crianças que não utilizam os produtos. ${ }^{5}$

\section{1- A Publicidade e o Código de Proteção e Defesa do Consumidor.}

A grande preocupação do direito é com os anunciantes que desrespeitam os valores sociais dos cidadãos. Uma vez que possuem a capacidade persuasiva, influenciando no comportamento das pessoas, necessária se tornou a intervenção do direito com a finalidade de melhor regulá-la em favor dos mais frágeis na relação de consumo. E, no direito brasileiro hoje vemos estampadas no $\mathrm{CDC}$, regras que, longe de

\footnotetext{
${ }^{5}$ WEBER, L.N.D. A criança, a TV e os videogames. São Paulo: Revista Elevação, 2001. 6p.
} 
prejudicar os anunciantes, carrega em seu bojo a proteção aos consumidores e o equilíbrio desta relação existente entre esses e os fornecedores.

Os direitos dos consumidores no Brasil são observados desde o Império, porém somente vieram a ser inseridos na Constituição em 1934, mas apenas a Constituição de 1988 que trouxe expressa a proteção ao consumidor. $\mathrm{O}$ CDC só teve sua promulgação em decorrência de mandamento constitucional posto no $\operatorname{art.5} 5^{\circ}$, XXXII, da CF/88, com a edição da Lei $n^{0} 8.078$, de 11 de setembro de 1990, que só entrou em vigor mesmo em 11 de março de 1991.

\section{2 - Publicidade e Propaganda}

Antes de adentrar no mérito do tema, é importante distinguir propaganda de publicidade. Apesar de muitos acreditarem que os termos são usados como sinônimos, isto é um erro, pois estes vocábulos não significam a mesma coisa.

A palavra propaganda vem do latim propagare, que quer dizer "fazer reprodução através de mergulhia", ou seja, enterrar, plantar, mergulhar, propagar princípios ou teorias. Define-se principalmente como a propagação de princípios e teorias. Traduzida precisamente em 1957 pelo Papa Clemente VII, através da fundação da Congregação da Propaganda, a qual tinha o objetivo de propagar o catolicismo no mundo. A propaganda visa a difusão de idéias ou convicções nos âmbitos político, filosófico, econômico, religioso, ideológico ou social. ${ }^{6}$

${ }^{6}$ CHAISE, Valéria Falcão. A publicidade em face do Código de Defesa do Consumidor. São Paulo: Saraiva, $2001.10 \mathrm{p}$. 
Já o termo publicidade é derivado de público, do latim publicus, e refere à qualidade do que é público. Expressa o ato de vulgarizar, de tornar público um fato, uma idéia. Vai ter como característica a comercialização, a negociação. È o que desperta nas pessoas o desejo de adquirir através da promoção de determinado agente econômico, seja institucional, seja de bem por ele produzido. Isto é, tem uma finalidade comercial. $^{7}$

Então, uma campanha governamental que visa diminuir o risco da transmissão de doenças sexualmente transmissíveis é uma propaganda, no entanto anunciar uma marca, é publicidade.

A doutrina tende a excluir a idéia de lucro da propaganda, quando não menciona a carência do propósito de incentivo ao consumo de produtos e serviços, marca da publicidade. Antônio Herman de Vasconcelos e Benjamin, anota:

"A publicidade tem um objetivo comercial (...) enquanto que a propaganda visa a um fim ideológico, religioso, filosófico, político, econômico ou social (...) A diferença essencial entre a publicidade e a propaganda baseia-se no fato de que a primeira fazse com a intenção de alcançar lucro, enquanto que a segunda exclui quase sempre a idéia de benefício econômico".

Adalberto Pasqualotto não reconhece a idéia do lucro na publicidade e a denomina:

"Toda comunicação de entidades públicas ou privadas, inclusive as não personalizadas, feita através de qualquer meio,

\footnotetext{
${ }^{7}$ JACOBINA, Paulo Vasconcelos. Publicidade no Direito do Consumidor. Rio de Janeiro: Forense, 1996, p. 8-9.

${ }^{8}$ GRINOVER, Ada Pellegrini et al.. Código Brasileiro de Defesa do Consumidor comentado pelos autores do anteprojeto. 4a ed. São Paulo e Rio de Janeiro: Forense Universitária, 1995, p. 196-197.
} 
destinada a influenciar o público em favor, direta ou indiretamente, de produtos ou serviços, com ou sem finalidade lucrativa". ${ }^{9}$

A intenção da obtenção do lucro com certeza é o aspecto diferenciador, logicamente para a publicidade. Assim, a intenção primordial da propaganda é a de não gerar lucros econômicos e sim de propagação de uma certa filosofia.

\section{3 - Publicidade Institucional e Promocional}

Nem toda mensagem publicitária tem como finalidade a colocação de produtos ou serviços no mercado. Há momentos em que o anunciante precisa melhorar seu conceito junto à opinião pública para reverter uma situação desfavorável, e há outros em que ele busca mostrar ao público uma faceta diferente. Assim, diante do exposto, a publicidade pode ser dividida em institucional ou promocional.

A Publicidade Institucional é aquela que anuncia a empresa, ou seja, a marca. Não é seu objetivo principal a venda de produtos ou serviços. Porém, em longo prazo esta finalidade tende a se concretizar pois, ao institucionalizar a marca, produtos ou serviços serão beneficiados, inclusive aqueles que ainda estão por vir. ${ }^{10}$ Por exemplo, a campanha de uma determinada empresa de carros que não anuncia nenhum modelo novo, apenas divulga a marca para não cair no esquecimento. ${ }^{11}$

\footnotetext{
${ }^{9}$ PASQUALOTTO, Adalberto. Op. Cit., p. 25.

${ }^{10}$ CHAISE, Valéria Falcão. Op. Cit., p. 13

${ }^{11}$ Um exemplo é a campanha da Ford durante a $2^{\text {a }}$ Guerra Mundial, onde não estavam sendo fabricados automóveis e para que a marca não caísse no esquecimento, surgiu o slogan "Há um Ford em seu futuro".
} 


\section{Explica Valéria Falcão:}

"Publicidade institucional é aquela que se destina a institucionalizar a marca. Aqui não existe a preocupação com a venda do produto em si; o que se anuncia é a própria empresa, e não o produto" ${ }^{12}$.

Por outro lado, a publicidade promocional busca exclusivamente vender produtos ou anunciar serviços ${ }^{13}$. Como exemplo, o anúncio de serviços prestados por uma empresa telefônica, a Vivo para o Dia dos Namorados ou, então, o anúncio do sabão em pó OMO.

\section{4 - Outras formas de Publicidade}

A publicidade não pode ser produzida da forma livre e espontânea, ou seja, o anunciante não pode veicular um produto da forma que ele achar conveniente, tendo em vista que o CDC veda uma série de meios de convencimento que são utilizados pelos publicitários.

A publicidade subliminar é um desses meios, pois ela estimula o consumo sem que receptor da publicidade perceba visualmente que está sendo estimulado, mas o subconsciente é capaz de captar a mensagem e aceita a sugestão por ela transmitida. Essa mensagem induz o consumidor a comprar sem a consciência. Uma vez que não é perceptível, ela não é permitida, já que possui técnicas psicológicas dirigidas ao subconsciente, com fins publicitários. Esse tipo de publicidade teve origem nos Estados Unidos, na década de 50, quando os cinemas de Nova Jersey passavam várias imagens, em frações de

\footnotetext{
${ }^{12}$ CHAISE, Valéria Falcão. Op. Cit., p. 13.

${ }^{13}$ Ibid. p. 14
} 
segundo, convencendo os freqüentadores a consumirem pipocas e refrigerantes. A venda desses dois produtos aumentou significativamente na época ${ }^{14}$.

A ONG Mensagem Subliminar, cujo objetivo é rastrear propagandas a procura de ações que sejam danosas ao público alvo das mesmas, interpelou a emissora MTV por apresentar mensagens subliminares de pedofilia e sadomasoquismo em uma de suas vinhetas e acusou a Unilever de usar palavrões em um frame do comercial da pasta de dente Close-up. A ONG afirma não ser correto o uso de palavrões escritos para expressar sentimentos de raiva e que deveriam ser usados símbolos como cobras, lagartos, escorpiões, etc. A Unilever se defende dizendo que seu intuito não era o de passar nenhuma mensagem subliminar, muito menos estimular o uso de palavrões e que o tema da campanha é "Se sua boca está falando mal de você, então mude para o creme dental Close-up" ${ }^{15}$.

Antônio Herman de Vasconcelos e Benjamin comenta:

"O legislador brasileiro não aceitou nem a publicidade subliminar (...) publicidade que não quer assumir a sua qualidade é atividade que, de uma forma ou de outra, tenta enganar o consumidor. E o engano, mesmo o inocente, é repudiado pelo Código de Defesa do Consumidor (...) O dispositivo visa impedir que a publicidade, embora atingindo o consumidor, não seja por ele percebida como tal (...) Veda-se, portanto, a chamada publicidade subliminar, especialmente sem sua forma redacional 116.

Publicidade de Denegrição também é outro meio vedado pelo $\mathrm{CDC}$, pois ela busca alcançar vantagens diminuindo as qualidades do

\footnotetext{
${ }^{14}$ CHAISE, Valéria Falcão. Op. Cit., p. 15.

15 Resumo da matéria veiculado no site "ONG Mensagem Subliminar". Veja outros casos em http://www.mensagemsubliminar.com.br. Acesso 06 de junho de 2005.

${ }^{16}$ GRINOVER, Ada Pellegrini et al. Op. Cit., p. $205-208$.
} 
concorrente e prejudicando-o. ${ }^{17}$ Abaixo a decisão do Conselho Nacional de Auto-Regulamentação Publicitária (“CONAR”), órgão cuja a missão é impedir que a publicidade cause algum constrangimento ao consumidor ou a empresas ${ }^{18}$ :

"Representação no $044 / 88$

Denunciante: Companhia Brasileira de Tratores

Denunciado: anúncio "Trator quebrou? E agora José?"

Anunciante: Instituto Universal Brasileiro

Relator: Conselheiro Ivo Rodrigues

$\mathrm{O}$ anúncio propunha aulas de mecânica por correspondência. Para isto exibiu, como ilustração do título "O trator quebrou. E agora José?", um modelo exatamente igual a um equipamento fabricado no Brasil. $\mathrm{O}$ fabricante (associado), afirmando que tal publicidade é lesiva à imagem do seu produto, ofereceu denúncia ao Conar.

$\mathrm{O}$ denunciado, em sua defesa, esclareceu que o anúncio fora produzido pelo veículo, não existindo de sua parte qualquer intenção de denegrir a imagem de produto ou de anunciante. $\mathrm{O}$ veículo, assumindo a responsabilidade pelo fato e excluindo-se de qualquer má-fé, informou que o anúncio foi imediatamente suspenso.

A empresa denunciante aceitou as escusas, dando por encerrada a questão. A Câmara, por isto, recomendou o arquivamento do feito, salientando, porém, que o anúncio seria fatalmente reprovado, caso não tivesse ocorrido a conciliação." $" 19$

Diferente da Comparativa que é aquela que o anunciante compara seu produto ou serviço com o do outro. Estas comparações são feitas através de elementos essenciais e verificáveis do produto ou serviço, uma vez que o conteúdo tem de ser absolutamente objetivo, não se admitindo a comparação que seja excessivamente geral. ${ }^{20} \mathrm{~A}$ comparação não pode denegrir o concorrente e nem confundir o consumidor. Os arts. 31 e 37 do $\mathrm{CDC}$ não tratou da Publicidade Comparativa, apenas tratou de forma genérica, ou seja, seja qual for o

\footnotetext{
${ }^{17}$ CHAISE, Valéria Falcão. Op. Cit., p. 11.

${ }^{18}$ Embora não seja um ente público, suas decisões nunca são desrespeitadas. Falaremos mais adiante a respeito deste Conselho.

19 Casos CONAR - Caderno 2 - Caso 10. Disponível em http://www.conar.org.br. Acesso em 06 de junho de 2005.

${ }^{20}$ Ibid. p. 16.
} 
modo, tem que respeitar seus princípios, principalmente $\mathrm{o}$ da veracidade. O exemplo de Publicidade Comparativa é da Central de Outdoor:

“Representação n' 230/03

Autora: Central de Outdoor

Anunciante e agência: Opportrans e Ronson

Relator: Carlos Chiesa

Decisão: Sustação

Fundamento: Artigos $1^{\circ}, 3^{\circ}, 5^{\circ}, 32$ letras c, f, e g e 50 letra c do Código

Anúncio em revista da Opportrans, empresa concessionária da exploração de publicidade no Metrô do Rio de Janeiro, mostra foto do que aparenta ser um outdoor cuja visão encontra-se encoberta por grande quantidade de árvores. $\mathrm{O}$ anúncio leva o título "Se a marca do seu cliente precisa aparecer, você não pode anunciar em qualquer lugar".

A Central de Outdoor pediu abertura de representação ética contra o anúncio considerando que ele "induz a falsa e pejorativa imagem do meio, ferindo as mais básicas condutas éticas do mercado publicitário". Houve concessão de liminar sustando a exibição da peça enquanto a Opportrans e sua agência preparavam defesa.

Nesta, negam a intenção de denegrimento e informam terem acatado de pronto a medida liminar.

O relator propôs sustação, voto aceito por unanimidade."21

\section{5 - Publicidade Enganosa}

O parágrafo primeiro do art. 37 do CDC define e exemplifica especificamente a Publicidade Enganosa. Entende-se como enganosa aquela que pode induzir o consumidor em erro, ou através da omissão, "quando deixa de informar sobre dado essencial do produto ou serviço" 22 , como bem coloca o parágrafo segundo do artigo supra citado, ou por meio da comissão, onde será afirmado algo que não é verdade, atribuindo mais qualidades ao produto ou ao serviço do que ele realmente possui, ou seja, se revela por uma afirmação inteira ou

\footnotetext{
${ }^{21}$ Casos CONAR - Decisões Outubro/2003. Disponível em http://www.conar.org.br. Acesso em 06 de junho de 2005.

${ }_{22}$ CAHALI, Yussef Said. Código Civil, Código de Processo Civil e Constituição Federal. $5^{\text {aed. São }}$ Paulo: Revista dos Tribunais, 2003. 1.206 p.
} 
parcialmente falsa sobre produto ou serviço. Ela se destaca por macular a declaração de vontade do consumidor. A publicidade enganosa vai provocar uma confusão na capacidade de decidir. Se o consumidor estivesse melhor informado, não adquiriria o que foi anunciado.

\section{Explica João Batista de Almeida:}

" A publicidade enganosa vicia a vontade do consumidor, que, iludido, acaba adquirindo produto ou serviço em desconformidade com o pretendido. A falsidade está diretamente ligada ao erro, numa relação de causalidade". ${ }^{23}$

Aduz também Fábio Ulhoa Coelho:

" É enganosa a publicidade capaz de induzir consumidores em erro quanto ao serviço ou produto em promoção (...) o decisivo é investigar se o conteúdo transmitido é suscetível de induzir em erro o consumidor do fornecimento em programação. Se, a partir da mensagem, se constata que ele pode ser levado a tomar por verdadeira a informação falsa, então caracteriza-se a publicidade enganosa". ${ }^{24}$

Assim, exempli gratia, o anúncio para a compra de um carro de luxo que, na realidade, não goza dessa classificação, ou a promessa de carro com vidro elétrico, ar-condicionado, travas, alarme, direção hidráulica, etc., quando não são verídicas essas informações. Se o consumidor adquire o aludido carro, seduzido pelas condições prometidas no contrato, na proposta ou no anúncio publicitário, e a realidade é que ele é de padrão de qualidade inferior, está-se perante a figura da publicidade enganosa por comissão.

\footnotetext{
${ }^{23}$ ALMEIDA, João Batista de. A Proteção Jurídica do Consumidor. São Paulo: Saraiva, 1993. 90 p.

${ }^{24}$ COELHO, Fábio Ulhoa. A Publicidade Enganosa no Código de Defesa do Consumidor. Revista de Direito do Consumidor, vol. 1, Revista dos Tribunais, p. 70-71.
} 
Não é necessária a intenção de enganar do anunciante, basta a mera indução em erro, não sendo necessária a existência de um dano. Vale ressaltar que no meio jurídico não existe um "direito adquirido de enganar", ou seja, o fornecedor não pode alegar que vem praticando várias vezes o mesmo tipo de anúncio. Neste caso, o erro é o mesmo que está nos artigos $138^{25}$ a $144^{26}$ do Código Civil (“CC"), ou seja, as manifestações de vontade viciadas com erro perdem totalmente sua eficácia.

O Erro Potencial pode estar vinculado a qualquer informação sobre sua natureza, características, qualidade, quantidade, propriedades, origem e preço. Já o Erro Real, consumado, é um mero exaurimento, que para fins de caracterização da enganosidade é irrelevante ${ }^{27}$.

O anunciante também não pode procurar afastar a sua responsabilidade argumentando que não teve intenção de causar danos ao consumidor ou de induzi-lo em erro. Não é importante o que deu origem a publicidade enganosa, apenas basta que a mensagem seja objetivamente capaz de causar a enganosidade. Explica Cláudia Lima Marques:

"Note-se que o artigo 37 do CDC não se preocupa com a vontade daquele que faz veicular a mensagem publicitária. Não perquire da sua culpa ou dolo, proíbe apenas o resultado: que a publicidade induza o consumidor a formar esta falsa noção da realidade. Basta que a informação publicitária, por ser falsa, inteira ou parcialmente, ou por omitir dados importantes, leve o

\footnotetext{
25 “art. 138. São anuláveis os negócios jurídicos, quando as declarações de vontade emanarem de erro substancial que poderia ser percebido por pessoa de diligência normal,em face das circunstâncias do negócio."

26 "art. 144. O erro não prejudica a validade do negócio jurídico quando a pessoa, a quem a manifestação de vontade se dirige, se oferecer para executa-la na conformidade da vontade real domanifestante."

${ }^{27}$ GRINOVER, Ada Pellegrini et al. Op. Cit., p. 291.
} 
consumidor ao erro, para ser caracterizada como publicidade proibida, publicidade enganosa ". ${ }^{28}$

Acresce Fábio Ulhoa Coelho:

"Ou seja, a tipificação da publicidade enganosa, para fins de responsabilização civil, independe de qualquer apreciação subjetiva, das intenções do fornecedor. Mesmo na hipótese de não ter o empresário agido com o intuito de enganar os consumidores, responde pelos danos advindos de publicidade enganosa". ${ }^{29}$

O Egrégio Tribunal de Justiça do Distrito Federal reconheceu a publicidade enganosa em um anúncio de um edifício de apartamentos que oferecia benfeitorias como piscina infantil, mini-golf, salão de jogos, salão de festas, entretanto esses apartamentos foram entregues sem o anunciado. O Desembargador Otávio Augusto enfatiza em seu voto:

"É indisfarçavel que o prometido na oferta, mesmo não constando deste último, integra o contrato que veio a ser celebrado, e à parte enganada se facultava não o desfazimento do negócio, mas a obtenção do abatimento do preço pago, em equivalência ao que deixou de ser construído e foi objeto de propaganda" ${ }^{30}$

O acórdão abaixo, proferido pelo Superior Tribunal de Justiça, mostra o quanto uma inverdade em um anúncio publicitário pode trazer de prejuízo, não só para o consumidor, como também para os concorrentes e para quem a anunciou, sem contar, ainda, que atingem o próprio Estado, principal interessado em manter um mercado de

\footnotetext{
${ }^{28}$ MARQUES, Cláudia Lima. Contratos no Código de Defesa do Consumidor. 2a ed. São Paulo: Revista dos Tribunais, 1995, $260 \mathrm{p}$.

${ }^{29}$ COELHO, Fábio Ulhoa. Op. Cit., p. 78.

30 APC n ${ }^{\circ}$. 27.980/92, relator o Des. Otávio Augusto, Registro de Acórdão nº. 82.038, DJDATA:01/08/2000.
} 
competição regulado e saudável. É uma publicidade que, não sendo verdadeira a sua mensagem, gerou concorrência desleal e, conseqüentemente, os consumidores que nela acreditaram, foram enganados quanto à qualidade do produto anunciado. Este é o acórdão:

Acórdão: RESP 60809/SP; RECURSO ESPECIAL (1995/0007135-5)

Fonte: DJDATA:01/08/2000PG:00255

RJADCOASVOL.:00016PG:00088

Relator(a)Min. ARI PARGENDLER (1104)

Data da Decisão: 29/06/1999

Órgão Julgador: T3 - TERCEIRA TURMA

Ementa: CIVIL. RESPONSABILIDADE CIVIL. DANO MORAL. PUBLICIDADE INVERÍDICA. A notícia, mesmo que divulgada pelo interessado, de que seu produto foi contemplado com a melhor avaliação em testes comparativos realizados por empresa especializada, não constitui dano moral ao concorrente, se a informação é verdadeira; mal contados os fatos, o dano moral que daí resulta é evidente, máxime se o produto desqualificado é um software, resultado de um trabalho intelectual, protegido como propriedade imaterial, em que a excelência é sempre perseguida, sendo desarrazoado pensar que, nessas circunstâncias, uma avaliação negativa em face do concorrente não tenha atingido a reputação da autora. Recurso especial conhecido e provido.

Decisão: Vistos, relatados e discutidos estes autos, acordam os Ministros da TERCEIRA TURMA do Superior Tribunal de Justiça, na conformidade dos votos e das notas taquigráficas a seguir, por unanimidade, conhecer do recurso especial e the dar provimento. Participaram do julgamento os Srs. Ministros Menezes Direito, Nilson Naves, Eduardo Ribeiro e Waldemar Zveiter.

Indexação: CABIMENTO, INDENIZAÇÃO, DANO MORAL, CONCORRENTE, DIVULGAÇÃO, PUBLICIDADE ENGANOSA, OBTENÇÃO, PRÊMIO, PRODUÇÃO, PROGRAMA DE COMPUTADOR, DESNECESSIDADE, COMPROVAÇÃO, PREJUÍZO, DECORRÊNCIA, NATUREZA JURÍDICA, OBRA INTELECTUAL.

(VOTO VOGAL) (MIN. CARLOS ALBERTO MENEZES DIREITO) RESSALVA, ENTENDIMENTO, REFERÊNCIA, DESCABIMENTO, PESSOA JURÍDICA, RECEBIMENTO, INDENIZAÇÃO, DANO MORAL.

Um anúncio que omite ou dificulta a visualização de algum dado essencial de um produto ou serviço, torna-se enganoso por omissão, uma vez que o anunciado é verdadeiro. A omissão relevante é aquela 
que, ciente dos dados sonegados, levaria o consumidor a não celebrar o contrato com o fornecedor ${ }^{31}$.

Destacamos, porém que, uma publicidade sem informações falsas ou imprecisas, também pode ser enganosa. É o caso, por exemplo, de mensagem que contém informações essenciais sobre o bem ou serviço ao consumidor estampadas em letras reduzidas e em sentido diverso (transversal, em um canto, etc.) ao da publicidade, dificultando a compreensão.

Fábio Ulhoa Coelho bem explica:

"A enganosidade por omissão, nesse sentido, se caracteriza na hipótese de se revelar de tal forma importante o dado omitido que tal consumidor-padrão deixaria de concretizar o negócio se dele soubesse anteriormente ". ${ }^{32}$

Adalberto Pasqualotto refere a importância da omissão:

"Mesmo sendo verdadeira, uma comunicação publicitária pode ser falsa, inteira ou parcialmente. A situação é freqüente quando há omissão de algum dado necessário ao conhecimento do consumidor, provavelmente determinante da compra". ${ }^{33}$

Antônio Herman de Vasconcelos e Benjamin adiciona:

"O Código nutre pela publicidade enganosa por omissão a mesma antipatia que manifesta pela publicidade enganosa comissiva. A enganosidade por omissão consiste na preterição de qualificações necessárias a uma afirmação, na preterição de fatos materiais ou na informação inadequada (...) $\mathrm{O}$ bom exemplo, tirado do mercado brasileiro, é o anúncio, feito pela Philips, de um televisor stereo, o primeiro a ser comercializado no País. Só que o anunciante deixou de informar ao consumidor que tal qualidade especial - que o distinguia de seus similares - só era alcançável com a aquisição, à

${ }^{31}$ GRINOVER, Ada Pellegrini et al. Op. Cit., p.216

${ }^{32}$ COELHO, Fábio Ulhoa. Op. Cit., p. 77.

${ }^{33}$ PASQUALOTTO, Adalberto. Op. Cit., p. 118-119. 
parte, de uma peça específica. Ora, o dado relevante para aquela aquisição - e por isso essencial - era exatamente a sua qualidade de sonoridade stereo". ${ }^{34}$

A enganosidade por omissão representa conduta reprovada pelo Código por afrontar os deveres de lealdade, transparência, identificação, veracidade e informação, que devem ser honrados pelo anunciante. Em um mercado de produção em massa, o consumidor se posiciona em situação inferior diante dos fornecedores, não se tolerando a adoção de técnicas de possível má-fé, particularmente a omissão de informações essenciais sobre os produtos anunciados. Procura-se a correta e suficientemente precisa informação das mensagens publicitárias, com vistas a possibilitar ao consumidor o livre juízo de conveniência de adquirir, ou não, produtos e serviços. Não deve a omissão na publicidade se prestar ao engano e à fraude. ${ }^{35}$

Se em uma publicidade identificarmos mais de uma interpretação e se uma delas for enganosa, já é o suficiente para entendermos o anúncio, como um todo, enganoso. Entende-se, todavia, que ao ser julgada como enganosa uma mensagem publicitária, é preciso que haja, além de conhecimento por parte do julgador, uma dose de bom-senso, a fim de se evitar abuso de direito por parte do consumidor. Como exemplo decisão do CONAR abaixo:

\footnotetext{
“Representação n' 302/03

Autor: Conar, a partir de queixa de consumidor

Anunciante e agência: Telefônica e DM9DDB

Relator: José Francisco Queiroz

Decisão: Alteração

Fundamento: Artigo $1^{\circ}, 3^{\circ} 27$ par $1^{\circ}$ e $2^{\circ}$ e 50 letra "b" do código.

Dois consumidores, um de São João da Boa Vista e outro de São Paulo, consideraram enganosa campanha promovendo o serviço de acesso a
}

\footnotetext{
${ }^{34}$ GRINOVER, Ada Pellegrini et al. Op. Cit., p. 225.
}

${ }^{35}$ PASQUALOTTO, Adalberto. Op. Cit., p. 126. 
internet Speedy. Para eles, a forma como a campanha foi estruturada leva à conclusão oposta: o consumidor pode entender como uma vantagem - "o Speedy pelo preço que você queria" - a nova apresentação do serviço, com limites de utilização e também mais caro que a versão anterior.

A defesa considerou a campanha de natureza informativa, não fazendo em momento algum comparações com o serviço anteriormente oferecido.

Alega ainda que as mensagens não dão ao consumidor a idéia de que o produto baixou de preço.

Para o relator, ao apresentar lettering que diz "agora o Speedy mudou o Speedy", a campanha oferece comparação, ao contrário do que argumenta a defesa. Ao mencionar nos comercias "pelo preço que você queria", os filmes remetem a uma oferta de preço esperada ou estipulada pela clientela. "Logo, escreve o relator, "é natural que o consumidor entenda que o preço do novo produto é obrigatoriamente menor que o já conhecido".

"O artigo 17 do Código deixa claro", prossegue o relator, "a importância de como a publicidade será entendida pelo consumidor, independente da intenção ou objetivo dos seus promotores. E, neste caso, o relator conclui que as mensagens induzem o consumidor a imaginar tratar-se de oferta de preço, o que não ocorre".

Ele sugeriu a alteração das mensagens da Telefônica, voto aceito por unanimidade. ${ }^{36}$

Enfim, a qualidade, a quantidade, a característica, a composição, o preço, a garantia, os prazos de validade, a origem e demais dados indispensáveis ou úteis ao conhecimento do consumidor acerca do produto e serviço que ele está adquirindo, devem ser informados por quem faz a oferta ou apresentação, exatamente como determina o art. 30 e 37 do CDC.

\section{6 - Publicidade Abusiva}

Deve-se distinguir a publicidade enganosa da publicidade abusiva. O parágrafo $2^{\circ}$ do artigo 37 do CDC define o que é a publicidade abusiva e elenca exemplos e hipóteses em que ela se verifica, ou seja, publicidade abusiva é, “dentre outras, a publicidade

\footnotetext{
${ }^{36}$ Casos CONAR - Decisões Dezembro/2003. Disponível em http://www.conar.org.br. Acesso em 06 de junho de 2005.
} 
discriminatória de qualquer natureza, a que incite à violência, explore o medo ou a superstição, se aproveite da deficiência de julgamento e experiência da criança, desrespeite valores ambientais, ou que seja capaz de induzir o consumidor a se comportar de forma prejudicial ou perigosa à sua saúde ou segurança", enfim, é aquela que ofende os valores sociais. $^{37}$ Esta é mais grave, pois induz o consumidor a se comportar de forma prejudicial.

As locuções "dentre outras", no $\S 2^{\circ}$, e "quaisquer outros", no $\S$ $1^{\circ}$ do artigo supra citado, fazem com que cheguemos à conclusão que os elencos da publicidade enganosa e abusiva são apenas exemplificativos, podendo existir outras formas de enganosidade e abusividade, cabendo aos aplicadores da lei, juízes e administradores, adaptarem o texto da regulamentação às práticas do mercado, ajustando-os aos valores éticos e sociais da pessoa e da família. Anota João Batista de Almeida:

"Não chega a ser mentirosa, mas é distorcida, desvirtuada dos padrões de publicidade escorreita e violadora de valores éticos que a sociedade deve preservar. Além disso, deturpa a vontade do consumidor, que pode, inclusive, ser induzido a comportamento prejudicial ou perigoso à sua saúde e segurança" ${ }^{38}$.

Publicidades de cigarros, bebidas alcoólicas, agrotóxicos, medicamentos e terapias, ou seja, tudo que acarreta alto risco para as pessoas, possui restrição de horários na veiculação no rádio ou na televisão, e conterá, sempre que for necessário, advertências sobre malefícios que podem causar em decorrência do seu uso contínuo. O mencionado está bem especificado no inciso II do parágrafo terceiro,

${ }^{37}$ CAHALI, Yussef Said. Op. Cit., p. 1.206.

${ }^{38}$ ALMEIDA, João Batista de. Op. Cit., p. 91 
bem como no parágrafo quarto do artigo 220 da Constituição Federal $(" \mathrm{CF} ")^{39}$.

Existe uma polêmica que envolve a veiculação de publicidade de cigarros, uma vez que ameaça a saúde pública. Inicialmente foi tentado disciplinar a publicidade tabagista através da Lei Murad, Lei no 9.294 de 15 de setembro de 1996, prevalecendo na doutrina a idéia de que se podia-se restringir os horários, ao invés de vedar.

Depois da lei supra citada vigorou a Lei Serra, Lei $\mathrm{n}^{\mathrm{o}}$ 10.167/2000, que vetou a publicidade em veículos de comunicação, autorizando-a somente na parte interna dos estabelecimentos que vedem o produto, evitando, assim, que não fumantes sejam influenciados por ela.

Isso tudo é o reflexo da indústria do fumo que atinge principalmente os jovens, que são estimulados com as belas paisagens, bonitas garotas e os prazeres de consumir o produto nocivo. Esses tipos de anúncios são claramente falsos tendo em vista os diversos estudos provando os males causados pelo hábito de fumar.

Em resolução divulgada em outubro de 2003, o CONAR definiu uma série de regras e parâmetros restritivos à propaganda de bebidas alcoólicas visando a não divulgação de imagens voltadas para menores. Foram retiradas pessoas de menos de 25 (vinte e cinco) anos nos comerciais, dentre outras. Mesmo assim, das mensagens que o Código

\footnotetext{
39 “art. 220. A manifestação do pensamento, a criação, a expressão e a informação,sob qualquer forma, processo ou veículo não sofrerão qualquer restrição,observado o disposto nesta Constituição... $\S 3^{\circ}$ Compete à lei federal: ... II - estabelecer os meios legais que garantam à pessoa e à família a possibilidade de se defenderem de programas ou programações de rádio e televisão que contrariem o disposto no art. 221, bem como da propaganda de produtos, práticas e serviços que possam ser nocivos à saúde e ao meio ambiente. $\S 4^{\circ}$ A propaganda comercial de tabaco, bebidas alcoólicas, agrotóxicos, medicamentos e terapias estará sujeita a restrições legais, nos termos do inciso II do parágrafo anterior, e conterá, sempre que necessário, advertência sobre os malefícios decorrentes do seu uso."
} 
Brasileiro de Auto-Regulamentação Publicitária resolve que deverão fazer parte obrigatória das cláusulas de advertência nos comerciais, apenas uma é voltada a informar que o consumo não se destina a crianças ou adolescentes ("Este produto é destinado a adultos”). As demais restringem o abuso, não beber e dirigir, e beber com moderação. No que compete ao controle do consumo, estudos recentes realizados nos EUA confirmam que a maioria dos estabelecimentos comerciais vende bebidas alcoólicas para indivíduos menores de 21 (vinte e um) anos, sem solicitação de verificação da idade. ${ }^{40}$

Um outro exemplo de publicidade abusiva discriminatória referese à veiculação de cartazes de uma marca de vestuários em que mostravam um padre (modelo trajando batina e capelo pretos) e uma freira (modelo com hábito e véu brancos) se beijando. A respeito do exposto, segue decisão do CONAR abaixo:

\footnotetext{
"Representação no 177/91

Denunciante: Conar, de ofício, mediante queixa de consumidor

Denunciado: anúncio "UNITED COLORS OF BENETTON"

Anunciante: BENETTON DO BRASIL TÊXTIL LTDA.

Relator $1^{\text {a }}$ instância: Cons. ${ }^{a}$ Vera Giangrande

Relator do Recurso Ordinário: Cons. ${ }^{\circ}$ Dr. Pedro Kassab

Relator do Recurso Extraordinário: Cons. ${ }^{\circ}$ Ricardo Rodrigues Pereira

O Anúncio

Veiculado em revistas e outdoors, legendado apenas com a assinatura "UNITED COLORS OF BENETTON", mostrava um padre (modelo trajando batina e capelo pretos) e uma freira (modelo com hábito e véu brancos) se beijando.
}

A Representação

Foi proposta pelo Conar, de ofício, em virtude de inúmeras queixas de consumidores, católicos, ofendidos com a referida publicidade e fundamentou-se nos artigos $1^{\circ}$ e 20 do CBARP.

A Defesa

Apresentada ao Conar se apoiou em argumentação depois repetida nas outras instâncias percorridas pelo processo. Em resumo, alegava que o anúncio, embora exibindo o beijo entre dois representantes da religião católica, não sugeriu volúpia, lascívia ou erotismo. Ao contrário,

${ }^{40}$ TOOMEY, TL / Wagenaar, AC. Environmental policies to reduce college drinking: options and research findings. J. Stud. Alcohol, Supplement, 2002. p.193-205. 
representava a afeição e o carinho em sua acepção mais fraterna. Por isso, não poderia o anúncio constituir ofensa ou desrespeito à Igreja ou aos católicos.

\section{Os Relatores do Processo}

Um em cada instância, foram três. Em $1^{\text {a }}$ instância o processo foi relatado pela Conselheira Vera Giagrande que opinou, e teve seu voto acolhido pela unanimidade da $2^{\mathrm{a}}$ Câmara, pelo arquivamento da representação, nos termos do artigo 24, $\mathrm{n}^{\circ}$ I, letra "a" do Regimento Interno.

$\mathrm{Na}$ Câmara Especial de Recursos pronunciou-se, como relator, o Conselheiro Dr. Pedro Kassab, cujo voto pela sustação da veiculação dos anúncios foi acolhida por maioria de votos.

O Recurso Extraordinário, levado a julgamento pelo Plenário do Conselho de Ética, foi relatado pelo Conselheiro Ricardo Rodrigues Pereira que, em sua manifestação, promoveu um acurado resumo dos atos e pareceres dos relatores anteriores. Suas conclusões foram as seguintes:

"O Brasil tem uma condição ímpar no mundo de pluralidade social, étnica, religiosa e econômica favorável, que o torna um país privilegiado entre os povos. O país nasceu sob o signo da cruz e foi forjado à sombra dos religiosos. A educação dos milhões de brasileiros espalhados por todo o país foi consolidada por centenas de anos, em sua grande maioria, por organizações religiosas. Padres e freiras, de ordens variadas ou seculares, embrenharam-se por este Brasil, oferecendo pão para os espíritos, ensinando a ler e a escrever e, mais que tudo, lutando sempre pela máxima evangélica de amor e respeito ao próximo. As figuras do padre e da freira são familiares a todos os brasileiros e estão geralmente presentes onde se encontram a aflição e a dor nos sanatórios, nas santas casas, nos orfanatos, nos asilos e nos leprosários. Mais do que pessoas, são símbolos vivos da caridade e do desprendimento e a sua marca se encontra nos mais longínquos rincões do país. Sobre eles paira a aura da docilidade, da compreensão e da pureza. Não cabe aqui discutir a importância ou não do celibato.

Cabe sim, reconhecer o trabalho diuturno e anônimo de milhares dessas criaturas, fazendo o bem. Quando, desconhecendo ou mesmo menosprezando este valor cultural brasileiro, uma empresa coloca no Brasil uma campanha onde um padre e uma freira se beijam, não se poderia esperar reação diferente da que vimos em todas as partes do Brasil, protestando contra essa agressão à sensibilidade cristã. Por mais que os nobres defensores queiram mostrar a pureza de intenções da presente campanha, utilizando depoimentos, fazendo a exegese das formas puras do beijo, deixando entrever nas suas declarações que os que não pensarem como eles poderão ser tachados de obscurantistas, nada disso esconde o fato de que tal propaganda agrediu parcela respeitável de brasileiros. Querer, igualmente, argumentar que os queixosos que se dirigiram ao Conar são pequena minoria da população é desconsiderar a inteligência dos membros desta Câmara. Temos um compromisso maior com o povo brasileiro e um respeito profundo pelo Conar. E não há dúvida que esta campanha publicitária, que utilizou o padre e a freira, atingiu duramente o modo de ser, a educação e o respeito que primam em nosso país. As manifestações internacionais dão conta de que reações diversas aconteceram em outros países. Achamos que é hora de, via Conar, o país mostrar que tem compromissos com a moral, com a verdade e com o 
respeito aos outros. A Constituição Federal dispõe que: "É livre a expressão da atividade intelectual, artística e científica e de comunicação, independentemente de censura ou licença". O mestre em Direito Penal, E. Magalhães Noronha, afirma que "em um Estado onde reine a liberdade, compreende-se que sejam admissíveis os debates, as críticas, as polêmicas de natureza religiosa, mas o crente tem o direito inconcusso de ser respeitado em sua fé". Uma das formas mais reconhecidas de fundamentação das normas morais é a tradição, coisa que os antigos souberam perceber e nos transmitir através da própria etimologia da palavra. Em função disso, é nosso entendimento que o comportamento social de um povo não seria possível sem que houvesse também uma compreensão do meio, no qual ele vive. As regras, leis, instituições, costumes e meios de comunicação, que regulam o comportamento social dos brasileiros, estão incluídos no componente sociológico da cultura, que serve de meio de relacionamento entre o homem e o ambiente físico e assim ajuda a preservação da vida e da nacionalidade.

Em face do exposto e considerando que os consumidores queixosos têm direito a uma resposta conclusiva, entende este relator que faltou sensibilidade à empresa anunciante, utilizando uma comunicação de forma abusiva e incomum, cujo único objetivo foi o de impactar a opinião pública com a mensagem publicitária; e sugere que sejam aplicadas as hipóteses previstas nas letras "a" e "c", do artigo 50, ou seja a advertência do anunciante e a sustação da veiculação dos anúncios.

A Decisão

A Decisão final consagrou, por maioria de votos, esse entendimento"41.

O Fornecedor deve não apenas se preocupar com a mensagem que está sendo transmitida, como também com o que está sendo veiculado, ou seja, deve ficar atento com a forma como vai ser passada a publicidade aos consumidores e como a mente deste público vai reagir.

É importante que seja lembrado mais uma vez que a publicidade é uma arma perigosa. Isso porque é um meio de influenciar pensamentos, valores, comportamentos e modificar condutas, como já comentado no início deste trabalho, por isso tem que ser controlada no

\footnotetext{
${ }^{41}$ Casos CONAR - Caderno 5 - Caso 28. Disponível em http://www.conar.org.br. Acesso em 06 de junho de 2005.
} 
caráter abusivo, pois ameaça à própria sociedade e aos valores que são o alicerce dela, os quais os anunciantes devem respeitar.

Vale ressaltar que o assunto abusividade visa também a proteção aos hipossuficientes e mais vulneráveis (crianças e velhos) e o respeito pelo meio-ambiente: "O anúncio não deve apregoar que um produto seja inócuo para o meio ambiente quando ele propiciar - de alguma forma - a elevação da temperatura terrestre." ${ }^{42}$

\section{7 - Técnicas da Publicidade}

Muitas técnicas são utilizadas no meio publicitário para incentivar o consumo.

O "teaser", que é uma das manobras comerciais mais utilizadas, procura despertar a curiosidade das pessoas ${ }^{43}$. Funciona como uma prépropaganda, ou seja, uma informação disponibilizada no mercado antes da propaganda propriamente dita, como se fosse uma preparação do que será anunciado. Um exemplo é quando primeiramente colocam um outdoor com os dizeres "um estilo de vida americano está chegando no Brasil", e alguns dias depois surgem outdoors com outros dizeres "Empreendimento Alphaville..."

\footnotetext{
${ }^{42}$ Representação n ${ }^{\circ}$ 083/97 - Sustação - Fundamento: artigos $1^{\circ}, 3^{\circ}, 33$, letra "a", e 50, letra "c", do CBARP - Relator Conselheiro Ênio B. Rodrigues - Primeira Câmara.

${ }^{43}$ CHAISE, Valéria Falcão.Op. Cit., p. 14.

${ }^{44}$ Outros exemplos famosos e recentes que recordamos são: 1) Propaganda da Vivo Celulares quando mudou o símbolo apareciam diversos bonequinhos sem informação, em seguida,veio a publicidade institucional; 2) Você viu o Sérgio ? Todos procuravam pelo Sérgio e não encontravam a resposta para a pergunta. Tempos depois, informaram que estava nos EUA comoseu American Express Card; 3) Outdoor: Juliana, Te amo. Assinado André. Era um anúncio do Rio Sul para o Dia dos Namorados. O André foi comprar o presente no shopping.
} 
Outra técnica bastante utilizada é o "puffing", que nada mais é do que o exagero publicitário. Porém, é muito importante que esse exagero não induza ninguém em erro ${ }^{45}$ Alegações gerais como "o melhor do mundo" têm que respeitar o parâmetro de fundamentação.

Vale comentar a respeito do "merchandising" que é o aparecimento de imagem de produtos ou serviços em entrevistas em televisão, rádio, revistas, jornais, novelas, seriados, etc., enfim, artigos publicados inseridos nos meios de comunicação em massa que estamos acostumados, que, a pretexto de ventilar novidades, se presta, na verdade, a veicular anúncios publicitários, iludindo o consumidor acerca do verdadeiro objetivo da reportagem. ${ }^{46}$ Essa técnica também é utilizada em novelas, por exemplo, fazendo-se com que os personagens consumam um determinado produto, como perfume ou utilizem um eletrodoméstico, ou freqüentem um determinado banco, hotel ou restaurante.

Antônio Herman de Vasconcelos e Benjamin explica melhor o "merchandising":

"Denomina-se merchandising em técnica publicitária (...) a aparição de produtos no vídeo, no áudio ou nos outros artigos impressos, em sua situação normal de consumo, sem declaração ostensiva da marca. Portanto, a comunicação é subliminar. Como exemplo podemos citar o consumo de cigarros, somente de determinada marca no filme, ou o uso exclusivo de carros da marca Ford numa determinada novela" ${ }^{47}$.

\section{8 - O Princípio da Veracidade}

\footnotetext{
${ }^{45}$ Ibid. p. 17,

${ }^{46}$ Ibid. p 16.

${ }^{47}$ GRINOVER, Ada Pellegrini et al. Op. Cit., p. 209.
} 
Evidencia-se nos artigos 36 e 37 da Lei Federal n ${ }^{\circ}$ 8.078/90, que o princípio basilar que rege a publicidade é o da veracidade. As mensagens publicitárias devem ser verdadeiras, em nome do respeito à boa-fé e também devido ao reconhecimento da vulnerabilidade do consumidor no mercado (art. 4o, III, fine, CDC) ${ }^{48}$, uma vez que os anúncios, no rádio, na televisão, nos out-doors, nas revistas, nos jornais, na internet e em tantos outros meios de comunicação, sempre têm o objetivo de atingir um público alvo, visando estimular o consumo de produtos e serviços. Exige a lei que as qualidades e características divulgadas, que vão atrair o consumidor sejam verídicas, autênticas.

James Marins, tratando deste princípio no CDC, esclarece:

"O Código adota o chamado "princípio da veracidade", ao qual deve ater-se o fornecedor sempre que preste informações, de qualquer natureza, sobre produtos e serviços". ${ }^{49}$

Para que a oferta obrigue o fornecedor é necessário que a proposta chegue ao conhecimento do consumidor, ou seja, que exista a exposição. Por força do princípio da veracidade, são proibidas nessas exposições as publicidades enganosas e abusivas.

A título de ilustração, abaixo dois acórdãos proferidos pelo Superior Tribunal de Justiça que caracterizam a vinculação do fornecedor que fez veicular a publicidade ou daquele que dela sebeneficiou:

Acórdão: RESP 139400/MG ; RECURSO ESPECIAL (1997/0047294-9)

Fonte: DJ DATA:25/09/2000 PG:00103

RT VOL.:00785 PG:00181

${ }^{48}$ CAHALI, Yussef Said. Op. Cit., p. 1.199.

${ }^{49}$ MARINS, James. Responsabilidade da Empresa pelo Fato do Produto. São Paulo: Revista dos Tribunais, Biblioteca de Direito do Consumidor, vol. 5, 1993, p.43 
Relator(a): Min. CÉSAR ASFOR ROCHA (1098)

Data da Decisão: 03/08/2000

Órgão Julgador: T4 - QUARTA TURMA

Ementa: PROCESSUAL CIVIL. CONSÓRCIO. TEORIA DA APARÊNCIA. LEGITIMIDADE PASSIVA RECONHECIDA. A empresa que, segundo se alegou na inicial, permite a utilização da sua logomarca, de seu endereço, instalações e telefones, fazendo crer, através da publicidade e da prática comercial, que era responsável pelo empreendimento consorcial, é parte passiva legítima para responder pela ação indenizatória proposta pelo consorciado fundamentado nesses fatos. Recurso conhecido e provido.

Decisão: Vistos, relatados e discutidos estes autos, acordam os Srs. Ministros da Quarta Turma do Superior Tribunal de Justiça, na conformidade dos votos e das notas taquigráficas a seguir, por unanimidade, conhecer do recurso e dar-lhe provimento. Votaram com o Relator os Srs. Ministros Ruy Rosado de Aguiar, Aldir Passarinho Júnior, Sálvio de Figueiredo Teixeira e Barros Monteiro.

Indexação: LEGITIMIDADE PASSIVA, PESSOA JURÍDICA, AÇÃO DE INDENIZAÇÃO, HIPÓTESE, AUTORIZAÇÃO, EMPRESA ADMINISTRADORA DE CONSÓRCIO,UTILIZAÇÃ̃O, NOME, LOGOTIPO, OBJETIVO, VENDA, CONSORCIO, VEICULO AUTOMOTOR, NECESSIDADE, APURAÇÃO, RESPONSABILIDADE CIVIL, TITULAR, DENOMINAÇÃO SOCIAL, DECORRÊNCIA, VINCULAÇÃO, NOME, ATO ILÍCITO, PUBLICIDADE ENGANOSA.

Referências: LEG:FED LEI:003071 ANO:1916

Legislativas: CC-16-CÓDIGO CIVIL - ART: 00159 ART:01518

LEG:FED LEI:008078 ANO:1990

CDC-90 CODIGO DE DEFESA DO CONSUMIDOR ART:00004 ART:00030

Acórdão: RESP 63981/SP; RECURSO ESPECIAL (1995/0018349-8)

Fonte: DJ DATA:20/11/2000 PG:00296

JBCC VOL.:00186 PG:00307

LEXSTJ VOL.:00139 PG:00059

RSTJ VOL::00137 PG:00389

Relator(a): Min. ALDIR PASSARINHO JUNIOR (1110)

Rel. p/ Acórdão: Min. SÁLVIO DE FIGUEIREDO TEIXEIRA (1088)

Data da Decisão: $11 / 04 / 2000$

Órgão Julgador: T4 - QUARTA TURMA

Ementa: DIREITO DO CONSUMIDOR. FILMADORA ADQUIRIDA

NO EXTERIOR. DEFEITO DA MERCADORIA.

RESPONSABILIDADE DA EMPRESA NACIONAL DA MESMA

MARCA ("PANASONIC"). ECONOMIA GLOBALIZADA.

PROPAGANDA. PROTEÇÃO AO CONSUMIDOR.

PECULIARIDADES DA ESPÉCIE. SITUAÇÕES A PONDERAR NOS

CASOS CONCRETOS. NULIDADE DO ACÓRDÃO ESTADUAL

REJEITADA, PORQUE SUFICIENTEMENTE FUNDAMENTADO.

RECURSO CONHECIDO E PROVIDO NO MÉRITO, POR MAIORIA. 
I - Se a economia globalizada não mais tem fronteiras rígidas e estimula e favorece a livre concorrência, imprescindível que as leis de proteção ao consumidor ganhem maior expressão em sua exegese, na busca do equilíbrio que deve reger as relações jurídicas, dimensionando-se, inclusive, o fator risco, inerente à competitividade do comércio e dos negócios mercantis, sobretudo quando em escala internacional, em que presentes empresas poderosas, multinacionais, com filiais em vários países, sem falar nas vendas hoje efetuadas pelo processo tecnológico da informática e no forte mercado consumidor que representa o nosso País. O mercado consumidor, não há como negar, vê-se hoje "bombardeado" diuturnamente por intensa e hábil propaganda, a induzir a aquisição de produtos, notadamente os sofisticados de procedência estrangeira, levando em linha de conta diversos fatores, dentre os quais, e com relevo, a respeitabilidade da marca.

II - Se empresas nacionais se beneficiam de marcas mundialmente conhecidas, incumbe-lhes responder também pelas deficiências dos produtos que anunciam e comercializam, não sendo razoável destinar-se ao consumidor as conseqüências negativas dos negócios envolvendo objetos defeituosos.

III - Impõe-se, no entanto, nos casos concretos, ponderar as situações existentes.

IV - Rejeita-se a nulidade argüida quando sem lastro na lei ou nos autos.

Decisão: Vistos, relatados e discutidos estes autos, prosseguindo no julgamento, acordam os Ministros da Quarta Turma do Superior Tribunal de Justiça, na conformidade dos votos e das notas taquigráficas a seguir, por maioria, conhecer do recurso e dar-lhe provimento, vencidos os Ministros Relator e Barros Monteiro. Votaram com o Ministro Sálvio de Figueiredo Teixeira os Ministros César Asfor Rocha e Ruy Rosado de Aguiar.

Indexação: EXISTÊNCIA, RESPONSABILIDADE, EMPRESA NACIONAL, PRODUTO DEFEITUOSO, AQUISIÇÃO, CONSUMIDOR, VENDEDOR, EMPRESA ESTRANGEIRA, INTEGRAÇÃO, IDENTIDADE, GRUPO ECONÔMICO, UTILIZAÇÃO, IDENTIDADE, MARCA, NECESSIDADE, MANUTENÇÃO, IGUALDADE, RELAÇÃO DE CONSUMO, EXISTÊNCIA, PROPAGANDA, INDUÇÃO, CONSUMIDOR, COMPRA, PRODUTO, DECORRÊNCIA, MARCA, EXISTÊNCIA, FAVORECIMENTO, EMPRESA NACIONAL, DECORRÊNCIA, UTILIZAÇÃO, MARCA, REPERCUSSÃO SOCIAL, MERCADO INTERNACIONAL.

(VOTO VISTA) (MIN. RUY ROSADO DE AGUIAR) EXISTÊNCIA, RESPONSABILIDADE, EMPRESA NACIONAL, PRODUTO DEFEITUOSO, AQUISIÇÃO, CONSUMIDOR, VENDEDOR, EMPRESA ESTRANGEIRA, INTEGRAÇÃO, IDENTIDADE, GRUPO ECONÔMICO, UTILIZAÇÃO, IDENTIDADE, MARCA, EXISTÊNCIA, RESPONSABILIDADE SUBSIDIARIA, PREVISÃO, CÓDIGO DE DEFESA DO CONSUMIDOR, IRRELEVÂNCIA, POSSIBILIDADE, FAVORECIMENTO, PRODUTO, OBJETO, CONTRABANDO, CARACTERIZAÇÃO, DIVERSIDADE, RELAÇÃO JURÍDICA.

(VOTO VENCIDO) (MIN. ALDIR PASSARINHO JUNIOR) INEXISTÊNCIA, RESPONSABILIDADE, EMPRESA NACIONAL, PRODUTO DEFEITUOSO, AQUISIÇÃO, CONSUMIDOR, 
VENDEDOR, EMPRESA ESTRANGEIRA, INTEGRAÇÃO, IDENTIDADE, GRUPO ECONÔMICO, UTILIZAÇÃO, IDENTIDADE, MARCA, CARACTERIZAÇÃO, DIVERSIDADE, PESSOA JURÍDICA, INAPLICABILIDADE, CÓDIGO DE DEFESA DO CONSUMIDOR, NEGOCIO JURÍDICO, REALIZAÇÃO, PAIS ESTRANGEIRO, IMPOSSIBILIDADE, EXTENSÃO, GARANTIA, ÂMBITO, TERRITÓRIO NACIONAL, NÃO CARACTERIZAÇÃO, FABRICANTE, INCLUSÃO, PRODUTO, MERCADO, IMPOSSIBILIDADE, FAVORECIMENTO, PRODUTO, OBJETO, CONTRABANDO, INEXISTÊNCIA, PUBLICIDADE ENGANOSA.

(VOTO VENCIDO) (MIN. BARROS MONTEIRO) INEXISTÊNCIA, RESPONSABILIDADE, EMPRESA NACIONAL, PRODUTO DEFEITUOSO, AQUISIÇÃO, CONSUMIDOR, VENDEDOR, EMPRESA ESTRANGEIRA, INTEGRAÇÃO, IDENTIDADE, GRUPO ECONÔMICO, UTILIZAÇÃO, IDENTIDADE, MARCA, CARACTERIZAÇÃO, DIVERSIDADE, PESSOA JURÍDICA, IMPOSSIBILIDADE, DESCONSIDERAÇÃO DA PERSONALIDADE JURÍDICA, NÃO OCORRÊNCIA, ABUSO DE DIREITO, EXCESSO DE PODER, ATO ILÍCITO, VIOLAÇÃO, LEI, CONTRATO.

Referências: LEG:FED LEI:008078 ANO:1990

Legislativas: CDC-90 CODIGO DE DEFESA DO CONSUMIDOR ART:00003 ART:00006 INC:00004 ART:00028 PAR:00002 PAR:00005 ART:00012 PAR:00003 INC:00001 


\section{CAPÍTULO III - A RESPONSABILIDADE DOS ENVOLVIDOS}

Não é surpresa que os profissionais da publicidade brigaram até o último momento contra a regulamentação pelo Estado das publicidades. As agências, os anunciantes, os comerciantes, as empresas, e muitos outros ofereceram, cada um da sua forma, resistência. $\mathrm{O}$ anunciante sempre tentará eximir-se de sua responsabilidade, à vista dos que buscam o direito, alegando a liberdade do pensamento e artística, desprezando os prejuízos que podem causar aos consumidores ${ }^{50}$.

Na maioria dos países as empresas aliadas estão se unindo com o objetivo de auto-regulamentar o trabalho publicitário, incluindo principalmente seus conselhos de ética ${ }^{51}$.

No Brasil, como exemplo de resistência, as empresas publicitárias se uniram e criaram o CONAR, sendo uma sociedade civil sem fins lucrativos, cabendo-lhe, dentre outras atribuições: funcionar como órgão judicante nos litígios éticos que tenham por objeto a indústria da propaganda ou questões a ela relativas, no âmbito administrativo e não judicial.

O Conselho de Ética do CONAR se baseia no Código Brasileiro de Auto-regulamentação Publicitária de 1978. Neste Código temos que os preceitos básicos que definem a ética publicitária são: "todo anúncio deve ser honesto e verdadeiro e respeitar as leis do país, deve ser preparado com o devido senso de responsabilidade social, evitando

\footnotetext{
${ }^{50}$ PASQUALOTTO, Adalberto. Op. Cit., p. 64.

${ }^{51}$ JACOBINA, Paulo Vasconcelos. Op. Cit. p. 28.
} 
acentuar diferenciações sociais, deve ter presente a responsabilidade da cadeia de produção junto ao consumidor, deve respeitar o princípio da leal concorrência e deve respeitar a atividade publicitária e não desmerecer a confiança do público nos serviços que a publicidade presta" ${ }^{, 52}$. Ainda no mesmo dispositivo legal, é determinado que, caso seja comprovada alguma infração, o responsável deverá ser punido com advertências, recomendações de alteração ou correção do anúncio, recomendações de sustação da veiculação e divulgação da posição do CONAR.

Uma vez que o CONAR é um conselho de iniciativa privada, não tem o poder coativo. Toda vez que o Conselho de Ética é provocado pelo judiciário para prestar informações, em virtude de Publicidade Enganosa ou Abusiva, a resposta é automática de que ele funciona apenas como consultoria para um anunciante ou uma agência ${ }^{53}$.

Para ilustração, Adalberto Pasqualoto, tomando por referência o Droit de la consommation (p.275), cita exemplos concretos:

"Atualmente, as atenções estão voltadas para o Canadá, onde a Suprema Corte daquele país encontra-se às vésperas de julgar causa que envolve proibição de publicidade de tabaco na Província de Quebec, já decidida, contra indústria fumageira interessada, na corte provincial. Segundo Nicole L'Heureux, tanto a Carta canadense quanto a quebequense protegem a liberdade comercial, sendo necessária a submissão ao judiciário de qualquer restrição legal de um direito de liberdade. Tratando-se de liberdade comercial, porém, as cortes canadenses são menos exigentes, não substituindo a sua interpretação pela do governo, apenas contentando-se em exigir a demonstração de um interesse jurídico que justifique a limitação."

\footnotetext{
${ }^{52}$ PASQUALOTTO, Adalberto. Op. Cit., p. 69.

${ }^{53}$ Ibid. p. 69.

${ }^{54}$ Ibid. p. 64.
} 
Conclui-se, então, que a liberdade de expressar o pensamento sem dúvida é um direito que a Carta Magna garante em seu art. $5^{\circ}$. No entanto, é preciso deixar bem claro que no direito brasileiro, principalmente com o fim comercial, que qualquer efeito nocivo de caráter moral ou material deverá recair a devida responsabilidade.

O direito do uso da palavra anda junto com sua devida responsabilidade. É necessária cautela ao lançar diante a população qualquer tipo de publicidade, tendo em vista que cada ser humano possui uma reação adversa.

A publicidade enganosa ou abusiva dá margem à responsabilização civil, penal e administrativa do fornecedor.

\section{1 - Responsabilidade Administrativa}

A publicidade abusiva e enganosa sofrem controle administrativo não só do órgão auto-regulamentador, o CONAR, como também dos órgãos públicos que garantem a defesa do consumidor, por força do estabelecido nos arts. 55 a 60 do CDC, que tratam das sanções administrativas.

A União, os Estados e Municípios fiscalizarão e controlarão a publicidade de produtos e serviços, com interesse na preservação da vida, da saúde, da segurança, da informação e do bem-estar do consumidor.

A contrapropaganda, como exemplo de sanção, é o anúncio imposto pela autoridade competente, após processo administrativo, nas mesmas dimensões em que foi propalado o anúncio enganoso, às custas 
do infrator, com observância das garantias do contraditório e da ampla defesa. ${ }^{55}$ Trata-se de veiculação de outra publicidade para sanar os malefícios causados pela publicidade originária, objetivando impedir a persuasão da publicidade enganosa ou abusiva, mesmo após a retirada da veiculação do meio de comunicação. Em suma, segundo o $\S 2^{\circ}$ do art. 60 do $\mathrm{CDC}^{56}$, o fornecedor, às suas expensas, informa corretamente ao consumidor, no mesmo veiculo de comunicação utilizado e com as mesmas características empregadas, no que se refere à duração, espaço, local e horário, desfazendo os erros do anúncio original. ${ }^{57}$

Somente após divulgada a contrapropaganda com o aviso prevenção aos consumidores a respeito do produto, é que o fornecedor fica eximido de sua responsabilidade de vinculação. Walter Ceneviva comenta o tema:

"Contrapropaganda, na relação de consumo, corresponde ao oposto da divulgação publicitária, pois destinada a desfazer efeitos perniciosos detectados e apenados na forma do CDC (...) punição imponível ao fornecedor de bens ou serviços, consistente na divulgação publicitária esclarecedora do engano ou do abuso cometidos em publicidade precedente do mesmo fornecedor (...) a imposição de contrapropaganda, custeada pelo infrator, será cominada (art. 62) quando incorrer na prática de publicidade enganosa ou abusiva (...) Quer a divulgação do anúncio, capaz de satisfazer a finalidade indicada seja feita em jornais e revistas, quer seja pela mídia eletrônica, seu custeio estará sempre a cargo do fornecedor (o fabricante, mesmo não destinando o produto ao destinatário final, pode ser sujeito passivo da obrigação)" ${ }^{158}$.

\footnotetext{
55 ALVIM, Arruda et al. Código Do Consumidor Comentado. 2. ed. rev. e ampl. Revista dos Tribunais; 1995, p.208.

${ }^{56}$ CAHALI, Yussef Said. Op. Cit., p. 1.212.

${ }^{57}$ GRINOVER, Ada Pellegrini et al. Op. Cit., p. 303.

${ }^{58}$ CENEVIVA, Walter. Publicidade e o Direito do Consumidor. São Paulo: Revista dos Tribunais, 1991, p. 132-137.
} 
Registre-se, aqui, o erro quando se empregou a expressão contrapropaganda (art. 56, XII, CDC), em vez de contrapublicidade, já que, conforme exposto no início da monografia, o termo publicidade é o mais adequado para fazer referência ao incentivo para a aquisição de produtos ou serviços ${ }^{59}$.

Por outro lado, o CONAR atende a denúncias de consumidores e autoridades e o seu Conselho se reúne e as julga, garantindo amplo direito de defesa ao acusado. O CONAR faz recomendações aos veículos de comunicação a suspensão da exibição da peça ou sugere correções à propaganda, podendo inclusive advertir anunciante e agência, sendo até mesmo capaz de adotar medida liminar de sustação no intervalo de algumas horas a partir do momento em que toma conhecimento da denúncia, impedindo que a publicidade enganosa ou abusiva cause constrangimento ao consumidor ou a empresas.

\section{2 - Responsabilidade Penal}

Em se tratando de sanções penais cabíveis, vale recorrer aos artigos 63, 66, 67, 68 e 69 do $\mathrm{CDC}^{60}$. Ou seja, “omitir dizeres ou sinais ostensivos sobre a nocividade ou periculosidade de produtos, nas embalagens, invólucros ou publicidade" (detenção de 6 meses à 2 anos e multa), assim como "fazer afirmação falsa ou enganosa, ou omitir informação relevante sobre natureza, característica, qualidade, quantidade, segurança, desempenho, durabilidade, preço ou garantia de produtos ou serviços" (detenção de 3 meses à 1 ano e multa), como

\footnotetext{
${ }^{59}$ PASQUALOTTO, Adalberto. Op. Cit., p. 25.

${ }^{60}$ CAHALI, Yussef Said. Op. Cit., p. 1212-1213.
} 
"promover publicidade que sabe ou deveria saber ser capaz de induzir o consumidor a se comportar de forma prejudicial ou perigosa a sua saúde ou segurança" (detenção de 6 meses à 2 anos e multa), ou "deixar de organizar dados fáticos, técnicos ou científicos que dão base à publicidade" (detenção de 1 à 6 meses ou multa), todos os exemplos acima expostos são passíveis de ação pública incondicionada e pena de detenção e multa, variando conforme cada caso.

A Lei 8.137 de 27 de dezembro de 1990, em seu Capítulo II, mais especificamente no art. $7^{\circ}$, também define crimes contra as relações de consumo:

"Art. 7. ${ }^{\circ}$ Constitui crime contra as relações de consumo:

I - favorecer ou preferir, sem justa causa, comprador ou freguês, ressalvados os sistemas de entrega ao consumo por intermédio de distribuidores ou revendedores;

II - vender ou expor à venda mercadoria cuja embalagem, tipo, especificação, peso ou composição esteja em desacordo com as prescrições legais, ou que não corresponda à respectiva classificação oficial;

III - misturar gêneros e mercadorias de espécies diferentes, para vendê-los ou expô-los à venda como puros; misturar gêneros e mercadorias de qualidades desiguais para vendê-los ou expô-los à venda por preço estabelecido para os demais mais alto custo;

IV - fraudar preços por meio de:

a) alteração, sem modificação essencial ou de qualidade, de elementos tais como denominação, sinal externo, marca, embalagem, especificação técnica, descrição, volume, peso, pintura ou acabamento de bem ou serviço;

b) divisão em partes de bem ou serviço, habitualmente oferecido à venda em conjunto;

c) junção de bens ou serviços, comumente oferecidos à venda em separado;

d) aviso de inclusão de insumo não empregado na produção do bem ou na prestação dos serviços;

$\mathrm{V}$ - elevar o valor cobrado nas vendas a prazo de bens ou serviços, mediante a exigência de comissão ou de taxa de juros ilegais;

VI - sonegar insumos ou bens, recusando-se a vendê-los a quem pretenda comprá-los nas condições publicamente ofertadas, ou retê-los para o fim de especulação;

VII - induzir o consumidor ou usuário a erro, por via de indicação ou afirmação falsa ou enganosa sobre a natureza, qualidade do bem 
ou serviço, utilizando-se de qualquer meio, inclusive a veiculação ou divulgação publicitária;

VIII - destruir, inutilizar ou danificar matéria-prima ou mercadoria, com o fim de provocar alta de preço, em proveito próprio ou de terceiros;

IX - vender, ter em depósito para vender ou expor à venda ou, de qualquer forma, entregar matéria-prima ou mercadoria, em condições impróprias ao consumo;

Pena - detenção, de 2 (dois) a 5 (cinco) anos, ou multa.

Parágrafo único - Nas hipóteses dos incisos II, III e IX pune-se a modalidade culposa, reduzindo-se a pena e a detenção de $1 / 3$ (um terço) ou a de multa à quinta parte."

\section{3 - Responsabilidade Civil}

Além da responsabilidade penal, o CDC também impõe uma responsabilidade civil aos vinculadores de publicidade enganosa ou abusiva, uma vez que a responsabilidade se origina de um efeito vinculativo da publicidade. É o que vem disposto no art. 30 do $\mathrm{CDC}^{61}$.

Através dessa idéia de vinculação que $\mathrm{o}$ fornecedor se compromete por toda e qualquer informação. Um bom exemplo para o exposto é o caso do Supermercado Sendas que anunciou um determinado produto dizendo ser o de menor preço no mercado, e quando vendeu não era. Obrigatoriamente o comerciante deve ofertar o produto com o menor preço. Assim, o consumidor terá uma maior proteção, tendo em vista que toda informação ou publicidade além de obrigar o fornecedor, também integra o contrato que vier a ser celebrado $^{62}$.

$\mathrm{O} \mathrm{CDC}$ atribuiu à publicidade uma natureza jurídica contratual. No momento em que o consumidor toma conhecimento de uma oferta via publicidade, dá-se o efeito vinculativo, e a partir do instante em que

${ }^{61}$ CAHALI, Yussef Said. Op. Cit., p. 1205.

${ }^{62}$ MARQUES, Cláudia Lima. Op. cit., p. 208-212. 
este consumidor manifesta seu interesse em aceitar o produto, a oferta passa a ser um contrato, mesmo que haja um documento assinado entre as partes no qual não conste discriminadamente o disposto na publicidade. O que foi anunciado integra o instrumento contratual, podendo, como qualquer outro negócio jurídico unilateral, ter revogação, nos limites da lei extinguindo o vínculo obrigacional. É o que pregam os artigos $30^{63}$ e $35^{64}$ do CDC.

Nas palavras de Adalberto Pasqualoto:

"Quando a mensagem publicitária é veiculadora de oferta, pode ser assemelhada a uma declaração unilateral de vontade, porque a lei obrigou o ofertante ao cumprimento" ${ }^{65}$.

O CDC inovou ao fazer referência a publicidade como oferta, como declaração unilateral de vontade, pré-contratual, que vincula o fornecedor e permite ao consumidor exigir o cumprimento do que anunciado, como apregoa Cláudia Lima Marques:

"No direito brasileiro, a oferta ou proposta é a declaração inicial de vontade direcionada à realização de um contrato (...) A oferta ou proposta é obrigatória, tem força vinculante em relação a quem a formula, devendo ser mantida por certo tempo. Basta, pois, o consentimento (aceitação ) do outro parceiro contratual e estará concluído o contrato (...) Se na visão tradicional a oferta já é um fator criador de vínculos, na visão do $\mathrm{CDC}$ este poder de vinculação (Bindung), desta declaração negocial, destinada ao consumo, é multiplicado (...) O art. 30, ao ampliar a noção de oferta e ao afirmar que as informações dadas integram o futuro contrato, revoluciona a idéia de invitatio ad offerendum. Agora,

\footnotetext{
63 “Art. 30. Toda informação ou publicidade, suficientemente precisa, veiculada por qualquer forma ou meio de comunicação, com relação a produtos e serviços oferecidos ou apresentados, obriga o fornecedor que a fizer veicular ou dela se utilizar e integra o contrato que vier a ser celebrado."

64 “Art. 35. Se o fornecedor de produtos ou serviços recusar cumprimento à oferta, apresentação ou publicidade, o consumidor poderá, alternativamente e à sua livre escolha: I - exigir o cumprimento forçado da obrigação, nos termos da oferta, apresentação ou publicidade; II - aceitar outro produto ou prestação de serviço equivalente; III - rescindir o contrato, com direito à restituição de quantia eventualmente antecipada, monetariamente atualizada, e a perdas e danos."

${ }^{65}$ PASQUALOTTO, Adalberto. Op. Cit., p. 60.
} 
qualquer informação ou publicidade veiculada que precisar, por exemplo, os elementos essenciais da compra e venda: res (objeto ) e pretium (preço), será considerada como uma oferta vinculante, faltando apenas a aceitação (consensus) do consumidor ou consumidores em número indeterminado (...) É o princípio da transparência nas relações de consumo, mesmo nessa fase anterior ao fechamento do negócio, exigindo veracidade nas informações que são transmitidas aos consumidores. A nova noção de oferta instituída pelo CDC nada mais é, portanto, que um instrumento para assegurar uma maior lealdade, uma maior veracidade das informações fornecidas ao consumidor ". ${ }^{66}$

Por fim, o Código do Consumidor dá ensejo à execução específica (arts. 35, I, e 84, § 1. ${ }^{\circ}$ ), consistindo opção exclusiva do consumidor a resolução em perdas e danos.

Conclui-se, então, a respeito da polêmica, que a publicidade, independente do efeito da mensagem, deve ser considerada como fonte de obrigação jurídica.

Mas vale deixar bem claro que não devemos interpretar o artigo 30 do CDC, com rigorosidade gramatical ou com extremo rigor formal. O simples fato de exagerar ao divulgar um bem ou serviço não vai obrigar o fornecedor. As expressões usadas com exagero, como "simplesmente a melhor", "a mais pedida", "a mais gostosa", apenas visam uma conotação qualitativa ao produto. Não há a obrigação até por uma questão de bom senso. Nada mais é do que um mero exagero ${ }^{67}$.

Também é isentada a responsabilidade quando o exagero se dá a título de fantasia nas peças publicitárias, contanto que o conteúdo fantasioso retrate, claramente, o absurdo. $\mathrm{O}$ importante é que não haja objetivo de ludibriar os destinatários. Não é nociva, por exemplo, uma

\footnotetext{
${ }^{66}$ MARQUES, Cláudia Lima. Op. cit., p. 208-212.

${ }^{67}$ CHAISE, Valéria Falcão.Op. Cit., p. 17.
} 
mensagem de guaraná que ao bebê-lo faz com que as garotas beijem a boca do rapaz para sentir o gosto. É obvio, guardando exceções, que nenhum consumidor irá supor que, toda vez que beber o produto, uma garota venha beijá-10 ${ }^{68}$.

\section{4 - A Responsabilidade dos Fornecedores}

No caso do fornecedor se recusar ao cumprimento da oferta, que foi decidida unilateralmente por ele visando seus interesses empresariais, que são, por evidente a obtenção de lucro, o consumidor pode, alternativamente e à sua livre escolha, "exigir o cumprimento forçado da obrigação" (art. 35, I, CDC), "aceitar outro produto ou prestação de serviço equivalente" (art. 35, II, CDC) ou "rescindir o contrato, com direito a restituição de quantia eventualmente antecipada, monetariamente atualizada, além de perdas e danos" (art. 35, III, CDC). As regras do art. 35 do $\mathrm{CDC}$ traduzem se preocupa em resguardar a boa-fé do consumidor, assegurando o cumprimento da palavra pelo proponente. $^{69}$

Por outro lado, quando um produto for utilizado da maneira incorreta e ocasionar danos ao consumidor provenientes de omissões na informação, o responsável deve reparar o dano, arcando com o prejuízo. Essa obrigação de reparação do dano é determinada através de pressupostos: o fato, o dano e o nexo de causalidade, acrescido de um fundamento, que como entende Pascoloto, se refere ao risco absoluto, em algumas hipóteses (danos nucleares, por exemplo) e ao risco moderado em outras (defeito do produto):

\footnotetext{
${ }^{68}$ Ibid, p. 17

${ }^{69}$ PASQUALOTTO, Adalberto. Op. Cit., p. 106.
} 
"no risco absoluto, basta o exercício da atividade propiciadora do dano. No risco moderado, não só a atividade perigosa é lícita, como o advento do dano em algumas circunstancias é tolerado (inexistência de defeito). A obrigação de indenizar deriva então de outro fator, abaixo do risco mas acima da culpa, qual seja, v.g., nos acidentes de consumo, o defeito do produto ou serviço" 70

O Código estabelece uma responsabilidade solidária, ou seja, o consumidor lesado pode reclamar tanto perante o fabricante do produto quanto do fornecedor, sendo facultado a estes o direito de regresso contra o verdadeiro responsável pelo dano. Facilita-se, assim, o acesso do consumidor à justiça, a fim de que suas pretensões sejam mais facilmente alcançadas.

O CDC (art. 38) adotou sistema na forma do qual o ônus da prova de que a publicidade não é falsa incumbe aos vinculadores, e não aos destinatários finais, e estabelece facilidades na defesa em juízo dos interesses dos vitimados pela mensagem publicitária enganosa ou abusiva. Com isso, além de punir os fornecedores, também protege o pólo mais vulnerável dessa relação, que é o consumidor, já que ele terá dificuldade em provar a "falsidade", a "omissão" ou a "ofensa" do anunciante ao divulgar a mensagem publicitária por ele recebida, igualando as partes desiguais, para criar uma harmonia no mercado consumista. É objetiva responsabilidade do fornecedor quanto à veracidade e correção do produto e/ou serviço anunciado.

Enfim, em se tratando de informações divulgadas mediante qualquer forma de oferta, veiculada por qualquer meio de comunicação social, vigora o princípio da responsabilidade do fornecedor à oferta e à publicidade, nos termos do art. 30 do CDC. Esse princípio demonstra o reconhecimento pelo

\footnotetext{
${ }^{70}$ Ibid., p. 170.
} 
Direito do poder de influência desse instrumento de informação nas decisões dos consumidores.

Aliás, a obrigação que tem o fornecedor de manter em seu poder os dados fáticos, técnicos e científicos que dão sustentação à mensagem (previsto no parágrafo único do art. 36) é a melhor maneira de se precaver caso necessite provar inocência em publicidade enganosa ou abusiva. Assim, o consumidor deverá provar que a mensagem foi divulgada e o anunciante deverá provar a veracidade do conteúdo.

Ressalta-se que a inversão é obrigatória. O art. 38 é taxativo: "O ônus da prova da veracidade e correção da informação ou comunicação publicitária cabe a quem as patrocina". ${ }^{71}$

Todavia, para se preservar a integridade dos valores protegidos pelo $\mathrm{CDC}$, além do princípio da responsabilidade do fornecedor à oferta, entendemos que se faz necessário estender a responsabilidade pela publicidade enganosa ou abusiva também àquelas pessoas que contribuíram, de forma decisiva, para o êxito na divulgação de tal mensagem, em troca de benefício patrimonial ou extrapatrimonial.

\section{5 - A Responsabilidade das Agências de Publicidade}

Uma parte da doutrina costuma estender a responsabilidade dos fornecedores pela publicidade abusiva ou enganosa também para as agências publicitárias, argumentando que essas entidades, embora estejam, quase sempre, comandadas pelo anunciante, dão à publicidade a característica de ilícito.

\footnotetext{
${ }^{71}$ CAHALI, Yussef Said. Op. Cit., p. 1206.
} 
Essa corrente, de forma mais sensata, também defende a idéia de que as agências publicitárias têm o dever de verificar as informações contidas no material fornecido pelo anunciante. As agências, pessoas jurídicas contratadas para fazer a publicidade, devem garantir que não hajam quaisquer equívocos relativos às informações contidas na linguagem publicitária que poderão gerar dúvidas quanto à intenção lesiva $^{72}$. Entre os doutrinares, Benjamin ressalta:

"... o quantum de responsabilidade da agência é maior nos casos de abusividade. Esta, em verdade, nasce quase sempre, no seio da própria agência"73

Por outro lado, há doutrinadores que criticam esse posicionamento, defendendo a irresponsabilidade das agências de publicidade por eventual publicidade abusiva ou enganosa, pois elas apenas realizam uma atividade sob a supervisão e a aprovação do anunciante $^{74}$. O próprio sistema do CDC desconsidera os problemas da cadeia de produção da publicidade e concentra-se no consumo e nos consumidores. ${ }^{75}$

\section{6 - A Responsabilidade das Celebridades}

Por outro lado, o raciocínio utilizado na tese que exclui a responsabilidade das agências publicitárias não se aplica aos casos em

\footnotetext{
${ }^{72}$ GUIMARÃES, Paulo. A publicidade ilícita e a responsabilidade civil das celebridades que dela participam. São Paulo: RT, 2001. 152 p. Também neste sentido, porém esclarecendo que a relação existente entre a agência e o anunciante não é de consumo, razão pela qual a responsabilidade da agência seria regulada pelo direito comum: LISBOA, Roberto Senise. Responsabilidade Civil nas Relações de Consumo. São Paulo: RT, 2001, 261 p.

${ }^{73}$ GRINOVER, Ada Pellegrini et al.. Op. it., p. 314.

${ }_{75}^{74}$ COELHO, Fábio Ulhoa. Op. cit., p. 162.

${ }^{75}$ MARQUES, Cláudia Lima. Op. cit., p. 351.
} 
que o produto ou o serviço é veiculado pelo apresentador de um programa ou um ator famoso. Nessas hipóteses, eles estão divulgando um produto ou serviço diretamente ao consumidor. São eles próprios que, aproveitando-se do carisma e da confiabilidade que eles têm com o público, oferecem o produto ou serviço e, como conseqüência, criam expectativas no receptor da mensagem, que deve ser protegido ${ }^{76}$.

A razão de se analisar também o trabalho desenvolvido pelos apresentadores e atores famosos dos meios de comunicação social de massa é inegável, pois eles são importantes na difusão do consumismo através da publicidade que veiculam.

Não podemos simplesmente ignorar os efeitos devastadores dos apresentadores e dos bonitos atores dos meios de comunicação social de massa. Como bem colocou Paulo Otero:

"A idéia de que uma imagem vale mais do que mil palavras nunca foi tão verdadeira"77.

Levando em consideração que a população brasileira, em sua maior parte, possui um baixo grau de instrução, podemos afirmar com toda convicção que espectador da oferta é, muitas vezes, "iludido" pelos apresentadores e atores. Com grande freqüência eles somente adquirem uma mercadoria por força da influência do transmissor da mensagem, que passa sua confiança e credibilidade ao produto.

Entretanto, quando os apresentadores e os atores vinculam a sua imagem ao produto ou serviço, mesmo que não estejam visando apenas

\footnotetext{
${ }^{76}$ PASQUALOTTO, Adalberto. Op. Cit., p. 28-29.

77 OTERO, Paulo. A Democracia Totalitária: Do Estado Totalitário à Sociedade Totalitária. A influência do totalitarismo na democracia do século XXI. Cascais: Principia Pub. Universitárias e Cientificas, 2001. p. 199.
} 
o lucro, ou mesmo que se preocupem com a qualidade do produto, ainda assim, também nessa hipótese, adquirem a imagem de garantidores, tendo em vista a confiança que as pessoas têm nos apresentadores e atores. Essa credibilidade é imediatamente transferida para o anúncio, transformando o produto ou o serviço anunciado em algo mais confiável e de qualidade atestada pela pessoa famosa.

Nesse caso, as pessoas que utilizam sua imagem nas publicidades tornam-se, verdadeiros parceiros do fornecedor, pois possuem grande importância na propagação dos produtos do anunciante.

Vale ressaltar que existe uma distinção entre a imagem das celebridades e a personagem. Quando a personagem é quem fala sobre o produto, não pode recair uma responsabilidade sobre o autor.

Podemos até questionar se existiria realmente a possibilidade dos apresentadores e atores terem o dever de controlar previamente o conteúdo da mensagem publicitária que será divulgada, tendo em vista que a publicidade não é uma manifestação de opinião ou pensamento, e sim um momento da atividade econômica produtiva da empresa e do apresentador ou ator famoso. ${ }^{78}$ Por outro lado, se o ator ou apresentador tem conhecimento que o produto é bom, deveria optar por não participar do anúncio, ou considerar esta hipótese, já que está vinculada a imagem dele àquele produto.

Contudo, não seria racional uma sociedade que garante o direito à liberdade de expressão ficar impossibilitada de interrogar os envolvidos a respeito das finalidades objetivadas, dos meios adotados, enfim, sobre a repercussão da sua ação. O direito à liberdade de

\footnotetext{
${ }^{78}$ GRINOVER, Ada Pellegrini et al. Op. Cit., p. 250.
} 
expressão é uma conseqüência direta da dignidade da pessoa humana e toda a manifestação do pensamento tem que ser verdadeira, íntegra e não pode ficar indiferente aos valores humanos. Vale ressaltar que deve ser imputado aos apresentadores de programas e atores um dever de apreciação da veracidade das informações levando em consideração a diligência do homem médio ${ }^{79}$.

Como o consumidor terá dificuldade em obter provas para esses casos, também deve ser aplicada a regra da inversão do ônus da prova, nos termos do artigo $6^{\circ}$, VIII, do $\mathrm{CDC}^{80}$. Ou seja, o apresentador e os atores devem provar que não houve imprudência ou negligência da parte deles ao afirmarem sobre a qualidade e características de um produto ou serviço.

Enfim, entendemos que os apresentadores e atores famosos podem vir a ser responsabilizados, ainda que subjetivamente, conforme o art. 186 do $\mathrm{CC}$ e art. $144^{\circ}$ do $\mathrm{CDC}$, pela publicidade enganosa e abusiva que causarem danos aos consumidores, recaindo também sobre eles o ônus da prova.

\section{7 - A Responsabilidade dos Veículos de Divulgação}

Por fim, diante dos princípios norteadores das relações consumeristas no Brasil, da vulnerabilidade evidente do consumidor frente à agressiva publicidade, diante do art. $6^{\circ}$, IV, do CDC que estabelece como direito básico do consumidor a proteção contra a

\footnotetext{
${ }^{79}$ GUIMARÃES, Paulo. Op. Cit. 152.

${ }^{80}$ Art. $6^{\circ}$ São direitos básicos do consumidor: "VIII - a facilitação da defesa de seus direitos, inclusive com a inversão do ônus da prova, a seu favor, no processo civil, quando, a critério do Juiz, for verossímil a alegação ou quando for ele hipossuficiente, segundo as regras ordinárias de experiências."
} 
publicidade enganosa ou abusiva, bem como olhos postos no parágrafo único do artigo $7^{\circ}$ do $\mathrm{CDC}$, que prevê a responsabilidade solidária quando a ofensa tiver mais de um autor, não vemos como afastar uma eventual responsabilização do sistema televisivo ${ }^{81}$.

Por outro lado, sabemos que diante da quantidade de anúncios transmitidos todos os dias pelos canais televisivos, é quase impossível fazer um controle prévio do que irá para o ar, ou seja, analisar produto por produto para não anunciar a publicidade enganosa ou abusiva. Por conta disso, a tendência nacional é eximir a responsabilidade dos veículos de divulgação no que tange material de terceiros. Tal princípio está expressamente definido na Carta Magna como direito e garantia fundamental. Em seu art. $5^{\circ}$, II, afirma a Constituição: "Ninguém será obrigado a fazer ou deixar de fazer alguma coisa senão em virtude de lei”.

Enfim, há responsabilidade em caso de notificação ou notória proibição, ou seja, quando o veículo de divulgação não deixar de veicular ao saber que a publicidade é ilícita, mas a jurisprudência tem eximido a responsabilidade dos transmissores da publicidade ${ }^{82}$.

Podemos citar o exemplo da responsabilidade dos Provedores de site na Internet, apesar da questão ainda ser muito recente no Brasil, porém em países como os Estados Unidos e Comunidade Européia, já temos jurisprudência referente a casos. A "Compuserve", um dos maiores Provedores de acesso à Internet do mundo, foi obrigada a

\footnotetext{
${ }^{81}$ LUCCA, Newton de et. al. Direito \& Internet - Aspetos Jurídicos Relevantes. $1^{\text {a }}$ ed. São Paulo: Editora Edipro, 2000, 354 p.

${ }^{82}$ Apenas para ilustração podemos citar o caso recente do jornal JB que foi condenado por vincular publicidade tabagista proibida por lei.
} 
desconectar, por decisão de um Tribunal alemão, cerca de 200 sites da rede porque veiculavam publicidade com matéria pornográfica. ${ }^{83}$

${ }^{83}$ LUCCA, Newton de et. al. Op. Cit. p. 354. 


\section{CONCLUSÃO}

É sabido por todos que os métodos persuasivos publicitários mais agressivos, excetuando-se as publicidades benéficas, são extremamente perigosos se utilizados irresponsavelmente. Alguns profissionais da publicidade se aproveitam da inocência e ignorância da população brasileira, altamente vulnerável diante deste mercado, para vender o seu produto, agindo justamente de forma contrária ao que é posto no CDC.

A publicidade é uma arma das indústrias, empresas e comércio, que por meio de métodos perigosos, pode manipular as mentes. Os anunciantes, as agências publicitárias, as celebridades e os veículos de divulgação algumas vezes deixam de respeitar os valores éticos e se utilizam de uma série de estratégias para a venda do produto ou serviço, em nome da remuneração que recebem, alegando estar no exercício de seu trabalho.

No entanto, o CDC veio com o intuito de proteger o consumidor. Com ele a publicidade passou a ser seriamente regulada e os interesses dos consumidores começaram a ser zelados por uma lei moderna, eficiente e de fácil compreensão.

As questões que envolvem a publicidade, ou seja, as considerações do código sobre obrigação pré-contratual, responsabilidade objetiva aos fornecedores e até tipificação penal de algumas condutas, vieram a impor uma considerável obrigação de respeito à ética dos consumidores vulneráveis a estas práticas.

Não podemos nos enganar, a publicidade influencia fortemente o consumidor e, em virtude disso, ela deve ser utilizada de forma sadia 
pelos fornecedores, além de atender aos preceitos legais impostos pelas lei consumerista. $\mathrm{O}$ anúncio publicitário não pode de maneira alguma infringir o contido no artigo 37 do $\mathrm{CDC}$, bem como o disposto nos artigos 63 a 69 do mesmo diploma legal, entre outras regulamentações que disciplinam a publicidade, como aquelas postas pelo Código Brasileiro de Auto-regulamentação Publicitária de 1978.

O que verificamos é que as publicidades enganosas e abusivas estão sendo empregadas por fornecedores que visam o lucro fácil em desconformidade com as leis. Para que os consumidores não sejam mais lesados, as medidas administrativas e penais devem ser tomadas pelo nosso judiciário e para isso, é necessário a denúncia ao Ministério Público daqueles que se sentem prejudicados.

O consumidor muitas vezes não tem a consciência dos direitos que efetivamente possui ou, por comodidade, não busca conhecê-los ou exige a sua aplicabilidade. Para que a sociedade se manifeste contra as propagandas enganosas ou abusivas, é necessário que todos tenham o conhecimento, pelo menos básico, dos seus direitos como consumidores.

Assim, precisamos ficar atentos ao que nos é ofertado através de anúncios escritos, falados e televisivos. Somente exercendo plenamente a nossa cidadania, estaremos preparados para o tratamento com dignidade e respeito nas relações tendenciosas de consumo.

Por fim, esse é um assunto que não se esgota, tamanha é a criatividade dos publicitários e, conseqüentemente, complexa é a atividade do legislador, pretensioso em resolver todas as questões, 
esperto quando não oferece enunciação legal taxativa ensejando possibilidades inúmeras por conta dos operadores do direito. 


\section{BIBLIOGRAFIA}

ALMEIDA, João Batista de. A Proteção Jurídica do Consumidor. São Paulo: Saraiva, 1993.

ALVIM, Arruda et al.. Código do Consumidor Comentado. São Paulo: Revista dos Tribunais, 1995.

BITTAR, Carlos Alberto. Direitos do Consumidor, $4^{\mathrm{a}}$ ed., Rio de Janeiro: Forense Universitária, 1995.

CANOTILHO, J.J. Gomes. Direito Constitucional e Teoria da Constituição. $2^{\text {a }}$ ed. Coimbra: Almedina, 1998.

CASADO, Márcio Mello. Princípios Gerais da Publicidade na Constituição Federal e no Código de Defesa do Consumidor, Revista Jurídica, novembro de 1999, nº 265.

CENEVIVA, Walter. Publicidade e o Direito do Consumidor. São Paulo: Revista dos Tribunais, 1991.

CHAISE, Valéria Falcão, A Publicidade em Face do Código de Defesa do Consumidor, São Paulo: Saraiva, 2001.

COELHO, Fábio Ulhoa. A Publicidade Enganosa no Código de Defesa do Consumidor. Revista de Direito do Consumidor, vol. 1, Revista dos Tribunais, São Paulo, p. 69-78, out./dez. 1993.

COELHO, Fábio Ulhoa. O Empresário e os Direitos do Consumidor. São Paulo: Saraiva, 1994.

DOMINGUES, Caio A., Publicidade Enganosa e Abusiva, São Paulo. Revista de Direito do Consumidor, $n^{\circ}$ 4, 1993.

FILOMENO, José Geraldo Brito. Manual de Direitos do Consumidor. $2^{a}$ ed. São Paulo: Atlas, 1991.

GRINOVER, Ada Pellegrini et al.. Código Brasileiro de Defesa do Consumidor comentado pelos autores do anteprojeto. $4^{\mathrm{a}}$ ed. São Paulo e Rio de Janeiro: Forense Universitária, 1995. 
GOMES, Marcelo Kokke. Responsabilidade Civil-Dano e Defesa do Consumidor, Belo Horizonte: Del Rey, 2001.

GUIMARÃES, Paulo. A publicidade ilícita e a responsabilidade civil das celebridades que dela participam. São Paulo: Revista dos Tribunais, 2001.

KOTLER, Philip. Administração de Marketing: análise, planejamento, implementação e controle. trad. Ailton Bomfim Brandão, $5^{\text {a }}$ ed. São Paulo: Atlas, 1998.

KELSEN, Hans. Teoria Geral do Direito e do Estado. Brasília: Universidade de Brasília, 1990.

LISBOA, Roberto Senise. Responsabilidade Civil nas Relações de Consumo. São Paulo: Revista dos Tribunais, 2001.

LUCCA, Newton de. Direito do Consumidor: São Paulo, Revista dos Tribunais, 1995.

MANDELBAUM, Renata. Contratos de Adesão e Contratos de Consumo. São Paulo: Revista dos Tribunais, 1996.

MARINS, James. Responsabilidade da Empresa pelo Fato do Produto. São Paulo: Revista dos Tribunais, Biblioteca de Direito do Consumidor, vol. 5, 1993.

MARQUES, Cláudia Lima. Contratos no Código de Defesa do Consumidor. $2^{\text {a }}$ ed. São Paulo: Revista dos Tribunais, 1995.

MELLO, Celso Antonio Bandeira. Curso de Direito Administrativo, $12^{\mathrm{a}}$ ed., São Paulo: Malheiros Editores, 2000.

MELLO, Sônia Maria Vieira de. O Direito do Consumidor na Era da Globalização: a descoberta da cidadania, Rio de Janeiro: Renovar, 1998.

NOVAIS, Alinne Arquette Leite, A Teoria Contratual e o Código de Defesa do Consumidor, São Paulo: Revista dos Tribunais, 2001.

NUNES, Luiz Antonio Rizzato. Comentários ao Código de Defesa do Consumidor: Direito material (arts. 1 o a 54). São Paulo: Saraiva, 2000. 
OTERO, Paulo. A Democracia Totalitária: Do Estado Totalitário à Sociedade Totalitária. A influência do totalitarismo na democracia do século XXI. Cascais: Principia Pub. Universitárias e Cientificas, 2001.

PASQUALOTTO, Adalberto. Os Efeitos Obrigacionais da Publicidade no Código de Defesa do Consumidor, São Paulo, Revista dos Tribunais, 1997.

RODRIGUES, Dirceu A Victor. Dicionário de Brocardos Jurídicos. $10^{\mathrm{a}}$ ed. São Paulo: Ateniense, 1994.

SILVA, José Luiz Toro da. Noções de Direito do Consumidor, Porto Alegre: Síntese, 1999.

SOIBELMAN, Leib. Enciclopédia do Advogado. $4^{\mathrm{a}}$ ed. Rio de Janeiro: Ed. Rio, 1983. 


\section{ANEXO: JURISPRUDÊNCIAS}

32072506 - DIREITO CIVIL - DIREITO DO CONSUMIDOR PRETENSA NULIDADE DE ATO ADMINISTRATIVO QUE FIXOU PENALIDADE AO FORNECEDOR EM FACE DE PUBLICIDADE ENGANOSA - REQUISITOS ESSENCIAIS DA OFERTA NO CÓDIGO DE DEFESA DO CONSUMIDOR - INVERSÃO DO ÔNUS PROBANDI - I - A apresentação e oferta de um produto ou serviço, em face do que dispõe o art. 31 do Código de Defesa do Consumidor, "devem assegurar informações corretas, claras, precisas, ostensivas e em língua portuguesa sobre suas características, qualidades, quantidade, composição, preço, garantia, prazos de validade e origem, entre outros dados, bem como sobre os riscos que apresentam à saúde e segurança dos consumidores". II - Dentre os princípios adotados pelo referido CODEX está o da transparência da fundamentação, cuja inobservância enseja a caracterização da propaganda enganosa por omissão, definida pelo artigo $37, \S 3^{\circ}$, CDC. III - Cabe ao fornecedor provar a veracidade e não-abusividade da publicidade veiculada sob sua responsabilidade. Inversão obrigatória do ônus da prova, por força do que estabelece o art. 38 do mesmo diploma. IV - Não há que se declarar a nulidade de ato administrativo representado por auto de infração que se alicerça nos limites da Lei de Regência dos Direitos do Consumidor, mormente quando inequivocamente demonstrada nos autos a conduta penalizada. $\mathrm{V}$ - Recursos voluntários conhecidos e providos, para, também em face do reexame necessário, reformar a r. Sentença. Conhecer e dar provimento aos recursos voluntário e oficial. Por maioria, vencido o desembargador vogal. (TJDF - APC 20000150007912 - $3^{\text {a }}$ T.Cív. Rel. Des. Wellington Medeiros - DJU 31.10.2000 - p. 22)

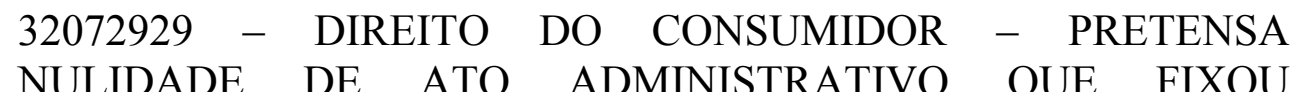
PENALIDADE AO FORNECEDOR EM FACE DE PUBLICIDADE ENGANOSA - REQUISITOS ESSENCIAIS DA OFERTA NO CÓDIGO DE DEFESA DO CONSUMIDOR - INVERSÃO DO ÔNUS PROBANDI - I - A apresentação e oferta de um produto ou serviço, em face do que dispõe o art. 31 do Código de Defesa do Consumidor, "devem assegurar informações corretas, claras, precisas, ostensivas e em língua portuguesa sobre suas características, qualidades, quantidade, composição, preço, garantia, prazos de validade e origem, entre outros dados, bem como sobre os riscos que apresentam à saúde e segurança dos consumidores". II - Dentre os princípios adotados pelo referido CODEX está o da transparência da fundamentação, cuja inobservância 
enseja a caracterização da propaganda enganosa por omissão, definida pelo artigo $37, \S 3^{\circ}$, CDC. III - Cabe ao fornecedor provar a veracidade e não-abusividade da publicidade veiculada sob sua responsabilidade. Inversão obrigatória do ônus da prova, por força do que estabelece o art. 38 do mesmo diploma. IV - Não há que se declarar a nulidade de ato administrativo representado por auto de infração que se alicerça nos limites da Lei de Regência dos Direitos do Consumidor, mormente quando inequivocamente demonstrada nos autos a conduta penalizada. $\mathrm{V}$ - Recursos voluntários conhecidos e providos, para, também em face do reexame necessário, reformar a r. Sentença. Conhecer e dar provimento aos recursos voluntário e oficial. Por maioria, vencido o desembargador vogal. (TJDF - APC 20000150008114 - 3 ${ }^{\mathrm{a}}$ T.Cív. Rel. Des. Wellington Medeiros - DJU 31.10.2000 - p. 23)

17019610 - PROMESSA DE COMPRA E VENDA DE IMÓVEL -
AÇÃO ORDINÁRIA RESTITUIÇÃO DE PARCELAS - RESTITUIÇÃO EM DOBRO MEMORIAL DE INCORPORAÇÃO - UNIDADE IMOBILIÁRIA DÚVIDA - REGISTRO DE ESCRITURA - REGISTRO DE IMÓVEIS - IMPOSSIBILIDADE - INCORPORAÇÃO IMOBILIÁRIA - CORRETOR DE IMÓVEIS - PROPAGANDA ENGANOSA - COMPROVAÇÃO - SENTENÇA CONFIRMADA "Promessa de Compra e Venda de Imóvel. Ação ordinária visando a rescisão do contrato, cumulada com pedido de devolução de todas as quantias pagas em dobro. Sentença que julgou, em conjunto, dois procedimentos distintos: rescisão de compra e venda formulada pelos promitentes compradores, fundamentada na diversidade da unidade prometida vender, em face do descrito no memorial de incorporação, e, pela incorporadora, com pedido reconvencional, alegando inadimplência dos compromissários. Imóvel anunciado e prometido vender com descrição diversa da constante do memorial de incorporação. Compromisso levado a registro que originou Dúvida julgada procedente. Título irregistrável do qual configuraram-se obrigações inexigíveis. Rescisão contratual formulada que se acolhe, em razão do não atendimento `a notificação premonitória efetivada pelos promitentes compradores. Argüição de publicidade enganosa do Incorporador e da Corretora, ao anunciarem a construção e venda de casas geminadas, triplex, posto que o memorial de incorporação referese a apartamentos. Defesa do Incorporador na qual se argumenta lapso do Cartório de Notas, visto que veio a constar a expressão "unidade 01, do bloco II", quando deveria constar apartamento 101, bloco II. Defesa da Corretora sustentando ser mera intermediária no negócio, a quem não se pode imputar responsabilidade pelas cláusulas contratuais. 
Quanto `a alegada publicidade dita enganosa, sustenta que esta incumbe à responsável pelo empreendimento. Inconsistência das argumentações despendidas, tanto pela Incorporadora, quanto pela Corretora, ante a descrição das unidades no memorial de incorporação. Restou devidamente comprovado que a procedência da Dúvida teve como conseqüência imediata a irregularidade do instrumento de promessa de compra e venda. O imóvel prometido vender é diverso do descrito no memorial de incorporação, gerando, daí, a irregularidade do título, bem como a publicidade enganosa. O vício do produto ou do serviço é flagrante e restou devidamente comprovado, seja com a Dúvida Registral, seja com o exame de propaganda do empreendimento trazido aos autos. Sentença que se mantem, também quanto aos dois outros procedimentos, uma vez que o acordo firmado gera conseqüências sobre a pretensão trazida a Juízo pela empresa, segunda apelante, da mesma forma que inviabiliza o pedido reconvencional. Recursos negados. (CLG)" (TJRJ - AC 15294/1999 - (11102000) - 18ª C.Cív. Rel. Des. Binato de Castro - J. 29.08.2000)

39022327 - INDENIZAÇÃO - ENTIDADE DE ENSINO - RECUSA NO OFERECIMENTO DE CURSO PREVIAMENTE CONTRATADO - CLÁUSULA CONTRATUAL ABUSIVA CÓDIGO DE DEFESA DO CONSUMIDOR - APLICABILIDADE PUBLICIDADE ENGANOSA - MÁCULA AO PRINCÍPIO DA CONFIANÇA - A publicidade formulada pelo Instituto Cultural Newton de Paiva Ltda., ora parte apelante, com intuito de atrair o maior número possível de candidatos para o seu vestibular, pode ser qualificada de enganosa, na medida em que os encartes publicitários do vestibular omitiram uma informação relevante para os candidatos, qual seja, que o curso oferecido não seria de tradutor e intérprete, mas apenas de tradutor. A atitude do Instituto Cultural Newton de Paiva Ltda., em não oferecer o curso de intérprete, violou o princípio consumerista da confiança, principalmente, se for levado em conta que todo encarte publicitário afirmava que o curso oferecido seria de tradutor e intérprete. Acrescente-se a isso, o fato de que os referidos encartes qualificavam a apelante como uma instituição de ensino séria e bastante preocupada em dar uma excelente formação aos seus alunos, o que, in casu, lamentavelmente, não se mostrou verdadeiro. DIREITO ECONÔMICO E DO CONSUMIDOR - PRINCÍPIO DA ANÁLISE ECONÔMICA COMO PARÂMETRO PARA FIXAÇÃO DO DANO MORAL - REPRESSÃO EFICIENTE À PRÁTICA ABUSIVA (PUBLICIDADE ENGANOSA) QUE MACULOU OS PRINCÍPIOS DA BOA-FÉ E DA CONFIANÇA E O MERCADO DE CONSUMO NO ESTADO DE MINAS GERAIS - INTELIGÊNCIA DO ART. 170, 
INCISO V, DA CF E ART. $4^{\circ}$, INCISO VIII E $6^{\circ}$, INCISO VI DA LEI $N^{\circ} 8.078 / 90$ - Nos casos envolvendo relação de consumo a reparação por dano moral assume uma finalidade bastante importante, qual seja, coibir e reprimir de modo eficiente todos os abusos praticados no mercado que possam causar prejuízos aos consumidores. A conduta do Instituto Cultural Newton de Paiva Ltda, de valer-se de publicidade enganosa para atrair o maior número possível de candidatos para o seu concurso de vestibular e para o seu curso de tradutor e intérprete, é gravíssima, pois violadora dos princípios da confiança e da boa-fé que devem nortear o mercado de consumo brasileiro. V.V.: A reprimenda, neste caso, deve ser proporcional ao prejuízo causado ao mercado de consumo de Minas Gerais, já que o vestibular da apelante tem alcance estadual. Por outro lado, deve também ser proporcional ao proveito econômico auferido pela apelante. Empregando-se o princípio da análise econômica, importante princípio de Direito Econômico, dá para mensurar que a apelante obteve uma vantagem econômica alta, já que o número de alunos lesados foi bastante considerável (cinqüenta e cinco) e o pagamento das mensalidades do curso se estendeu por longos 4 anos. Destarte, se o Poder Judiciário quiser realmente exercer a sua função constitucional de tutelar o mercado de consumo brasileiro deve, em casos como o ora retratado, adotar postura corajosa e enérgica, abandonando, assim, a estipulação de valores módicos para as indenizações. Desse modo, considerando que o valor estipulado pelo douto juiz a quo (sessenta mil reais) é adequado para coibir e reprimir de modo eficiente o abuso (publicidade enganosa) praticado pela apelante no mercado de consumo de Minas Gerais, não há motivo para a redução da reparação por dano moral. (TAMG - Ap 0298792-6 (29594) - 4ª C.Cív. - Rela . Juíza Maria Elza - J. 29.03.2000)

34021706 - CAMPANHA PROMOCIONAL - SORTEIO DE PRÊMIO - CARTELA DEFEITUOSA - INSUFICIÊNCIA DE INFORMAÇÕES - CULPA DOS FORNECEDORES - PRÊMIO DEVIDO - DENUNCIAÇÃO À LIDE - CONDENAÇÃO SOLIDÁRIA - AUSÊNCIA DE SUPORTE LEGAL - A omissão de informação relevante em torno de regras que compõem campanha promocional denota publicidade enganosa, impondo-se o pagamento do prêmio ao consumidor que, induzido a erro, é levado a pensar que logrou preencher os requisitos exigidos para tal fim. - Não há relação de direito material entre o autor da ação principal e o denunciado à lide, o qual, por isso, não pode ser condenado a pagar, solidariamente com o réu denunciante, o valor fixado na condenação. (TAMG - AC 03076991 - $1^{\text {a }}$ C.Cív. - Rel. Juiz Silas Vieira - J. 20.06.2000) 
17016638 - DIREITO DO CONSUMIDOR - PUBLICIDADE EM LISTA TELEFÔNICA - CELEBRAÇÃO DO CONTRATO PROPAGANDA ENGANOSA - VÍCIO DE VONTADE ANULAÇÃO DO CONTRATO - Lista telefônica. Contrato de publicação. Meio enganoso. Invalidade do negócio. Provado que a anunciante só contratou porque foi convencida de que os números de suas linhas telefônicas seriam mudados, fato este que não ocorreu, anula-se o negócio por ter havido distorção no processo decisório. Nas relações de consumo, regidas pelos princípios da transparência, confiança e boa-fé, não há lugar para expediente astucioso destinado à obtenção de proveito econômico. Desprovimento do recurso. (LCR) (TJRJ - EI-AC 447/1999 - (23022000) - I C.G.Cív. - Rel. Des. Sérgio Cavalieri Filho - J. 24.11.1999)

17014873 - PUBLICAÇÃO JORNALÍSTICA - PROPAGANDA ENGANOSA - VIOLAÇÃO DE NORMA LEGAL - ART. 31 - ART. 36 - ART. 37 - PARÁGRAFO ÚNICO - LEI No 8.078, DE 1990 (VIDE: CÓDIGO DE DEFESA DO CONSUMIDOR) - DANO MORAL - ARBITRAMENTO - VALOR DA INDENIZAÇÃO Publicidade enganosa. Oferta de ingressos de cinema. Redação do anúncio. Compreensão difícil. Constrangimento do consumidor. Violação dos arts. 31, 36 e 37 parágrafo único da Lei $\mathrm{n}^{\mathrm{o}}$ 8.078. Dano moral. Arbitramento. I - É enganosa a publicidade veiculada em jornal que, pela apresentação gráfica do anúncio, enseja ao consumidor menos atento acreditar que a simples apresentação daquele "vale-ingresso" permite assistir a sessão de cinema gratuitamente. II - A situação de constrangimento que a negativa de aceitação do "vale-ingresso", na porta da sala de espetáculos, dá ao consumidor logrado o direito de reparação. As chacotas, ditos chistosos e risotas, ainda que não tenham vindo dos prepostos da ré, foram gerados por eles ao recusarem o cumprimento à oferta feita no jornal. III - A indenização deve ser arbitrada de maneira moderada, considerando-se as peculiaridades dos envolvidos, porém não pode ser exígua a ponto de seu valor não servir de reprimenda aos infratores da Lei $\mathrm{n}^{\mathrm{o}}$ 8.078. Daí porque se impõe a majoração da condenação de 05 para 50 salários-mínimos para cada uma das autoras. IV - Apelação das consumidoras provida em parte, improvendo-se os recursos das res. (TJRJ - AC 2.748/1999 - (Ac. 23061999) - 17ª C.Cív. - Rel. Des. Bernardo Garcez - J. 05.05.1999)

700054 - JCF.5.LXXIII JCF.37.1 AÇÃO POPULAR - ART. 5º, LXXIII DA CONSTITUIÇÃO FEDERAL C/C O ART. $1^{\circ}$ E SEGUINTES DA LEI 4.717/65 - PROPAGANDA DAS OBRAS REALIZADAS - PUBLICIDADE ROTULADA DE ILEGAL E 
ABUSIVA - POSSÍVEL USO DO ERÁRIO PÚBLICO COM OBJETIVO DE FUTURA CANDIDATURA ELEITORAL AUSÊNCIA DE LESIVIDADE DO ATO AO PATRIMÔNIO PÚBLICO - IMPROCEDÊNCIA DA AÇÃO - RECURSO EX OFFICIO - SENTENÇA MANTIDA EM GRAU DE REEXAME INTELIGÊNCIA DO ART. 19 DA LEI DE REGÊNCIA DA AÇÃO POPULAR CONSTITUCIONAL E ART. 37, $\S 1^{\circ}$ DA CONSTITUIÇÃO FEDERAL - (01) Ação Popular. Improcedência. Necessidade de recurso de Ofício. Quando a sentença proferida na ação popular constitucional é contrária ao pedido do autor, mesmo ausente o recurso voluntário só se pode falar em decisão transitada em julgado após o reexame da sentença pelo Tribunal, eis que o art. 19 da Lei de Regência da Ação Popular determina que se o juiz concluir pela improcedência do pedido ou pela carência da ação, recorrerá de ofício. (02) Ação popular. Improcedência. Inexistência de provas de lesividade ao patrimônio. Confirma-se integralmente a decisão prolatada na ação popular constitucional - que julgou improcedente o pedido vestibular se nos autos restou demonstrado que $\mathrm{o}$ ato atacado não produziu qualquer lesividade ao patrimônio público. (03) Publicidade. Limites legais. Caráter meramente informativo sem promoção pessoal. Admissibilidade ( $\S 1^{\circ}$ do Art. 37 do C.F.). Os atos publicitários hostilizados, revelando os programas, as obras, os serviços e as campanhas dos órgãos públicos, podem ser objeto de divulgação, desde que a publicidade tenha natureza educativa, informativa ou de orientação social e da propaganda não conste elementos que caracterizem, concretamente, promoção pessoal de autoridades ou servidores públicos. (TJPR - REO 46692-4 - Ac. 12.754 -- 1 $^{\mathrm{a}}$ C.C. - J. 18.06.1996) 